\title{
Transmission dynamics of SARS-CoV-2 in the hospital setting
}

3 Yin Mo ${ }^{1,2,3,4}$, David W. Eyre ${ }^{5,6,7,8}$, Sheila F. Lumley ${ }^{6}$, Timothy M. Walker ${ }^{1,6,10}$, Robert H.

4 Shaw $^{6}$, Denise O’Donnell ${ }^{6}$, Lisa Butcher ${ }^{6}$, Katie Jeffery ${ }^{6}$, Christl A. Donnelly ${ }^{11,12}$, Oxford

5 COVID infection review team*, and Ben S. Cooper ${ }^{1,2}$

1. Oxford Centre for Global Health Research, Nuffield Department of Medicine,

13 4. Department of Medicine, National University of Singapore

14 5. Big Data Institute, Nuffield Department of Population Health, University of Oxford,

15 Oxford, United Kingdom

16 6. Oxford University Hospitals, NHS Foundation Trust, Oxford, United Kingdom

17 7. NIHR Oxford Biomedical Research Centre, University of Oxford, Oxford, United

$18 \quad$ Kingdom

19 8. NIHR Health Protection Research Unit in Healthcare Associated Infections and

20 9. Antimicrobial Resistance at University of Oxford in partnership with Public Health

$21 \quad$ England, Oxford, United Kingdom

22 10. Oxford University Clinical Research Unit, Ho Chi Minh City, Vietnam 
23 11. Department of Statistics, University of Oxford, Oxford, United Kingdom

24 12. MRC Centre for Global Infectious Disease Analysis, Department of Infectious Disease Epidemiology, Imperial College London

$27 *$ Full list of members in the Oxford COVID infection review team is provided in the 28 supplementary material section 9.

29

30 Corresponding author: Yin Mo moyin@tropmedres.ac

31

32 Keywords: SARS-CoV-2, nosocomial transmission, infection prevention and control

33

34 Word count:

35 Abstract 269 words

36 Manuscript 3430 words

37 
medRxiv preprint doi: https://doi.org/10.1101/2021.04.28.21256245; this version posted May 1, 2021. The copyright holder for this preprint (which was not certified by peer review) is the author/funder, who has granted medRxiv a license to display the preprint in perpetuity.

It is made available under a CC-BY-NC-ND 4.0 International license .

\section{Abstract}

Background: SARS-CoV-2 can spread efficiently in hospitals, but the transmission pathways

41 amongst patients and healthcare workers are unclear.

43 Methods: We analysed data from four teaching hospitals in Oxfordshire, UK, from January to

44 October 2020. Associations between infectious SARS-CoV-2 individuals and infection risk were

45 quantified using logistic, generalised additive and linear mixed models. Cases were classified as

46 community- or hospital-acquired using likely incubation periods.

48 Results: Nine-hundred and twenty of 66184 patients who were hospitalised during the study

49 period had a positive SARS-CoV-2 PCR test within the same period (1\%). Out of these, 571

50 patients had their first positive PCR tests while hospitalised (62\%), and 97 of these occurred at

51 least seven days after admission (11\%). Amongst the 5596 healthcare workers, $615(11 \%)$ tested

52 positive during the study period using PCR or serological tests. For susceptible patients, one day

53 in the same ward with another patient with hospital-acquired SARS-CoV-2 was associated with

54 an additional eight infections per 1000 susceptible patients (95\%CrI 6-10). Exposure to an

55 infectious patient with community-acquired COVID-19 or to an infectious healthcare worker was

56 associated with substantially lower infection risks (2/1000 susceptible patients/day, 95\%CrI 1-2).

57 As for healthcare worker infections, exposure to an infectious patient with hospital-acquired

58 SARS-CoV-2 or to an infectious healthcare worker were both associated with an additional one

59 infection per 1000 susceptible healthcare workers per day (95\% CrI 1-2). Exposure to an 
60 infectious patient with community-acquired SARS-CoV-2 was associated with half this risk

$61(0.5 / 1000$ susceptible healthcare workers/day, 95\%CrI 0.3-0.7).

62

63 Interpretation: Exposure to patients with hospital-acquired SARS-CoV-2 poses a substantial

64 infection risk. Infection control measures to limit nosocomial transmission must be optimised to

65 protect both staff and patients from SARS-CoV-2 infection.

66

67 Funding: National Institute for Health Research Health Protection Research Unit (NIHR HPRU)

68 in Healthcare Associated Infections and Antimicrobial Resistance at Oxford University in

69 partnership with Public Health England (PHE) (NIHR200915). Medical Research Council,

70 Nosocomial transmission of SARS-CoV-2 (MR/V028456/1).

71

72 
medRxiv preprint doi: https://doi.org/10.1101/2021.04.28.21256245; this version posted May 1, 2021. The copyright holder for this preprint (which was not certified by peer review) is the author/funder, who has granted medRxiv a license to display the preprint in perpetuity.

It is made available under a CC-BY-NC-ND 4.0 International license .

\section{Research in context}

\section{Evidence before this study}

75 We searched the PubMed database using the search terms ("COVID-19" OR "SARS-CoV-2")

76 AND ("nosocomial" OR "hospital") AND ("transmission") in either the abstracts or titles, for

77 English-language articles published up to March 31, 2021. This returned 748 results, out of

78 which ten reported transmission events in the hospital setting quantitatively. These publications

79 can be broadly categorised to epidemiological descriptions of isolated outbreaks (5) or contact

80 tracing of patients exposed to infected healthcare workers (1), retrospective cohort studies

81 involving a particular group of patients, e.g., patients who underwent surgical procedures (2),

82 and using genomic sequencing to identify transmission clusters (2). None of the studies reported

83 the comparative transmission rates of SARS-CoV-2 amongst patients and staff.

\section{Added value of this study}

86 This study reports the analysis of a large observational dataset collected from a group of

87 hospitals in the UK over eight months, consisting of both hospitalised patients and healthcare

88 workers. Based on these detailed individual-level data, we quantified the associations between

89 patient and healthcare worker characteristics and risks for acquiring nosocomial SARS-CoV-2

90 infection after adjusting for their exposures to SARS-CoV-2. Over the study period, we describe

91 how risk of acquisition changes both with calendar time and over a patient's hospital stay. By

92 linking the presence of infected and susceptible patients and healthcare workers by time and

93 ward locations, we quantify the relative importance of the transmission pathways for both the

94 susceptible patients and healthcare workers. 


\section{Implications of all the available evidence}

97 Nosocomial transmission of SARS-CoV-2 is common. Identifying the drivers of SARS-CoV-2

98 transmissions in the hospital setting is essential for designing infection prevention and control

99 policies to minimise the added pressure from such events on our health systems. We found that

100 newly infected patients who acquired SARS-CoV-2 in the hospital pose the highest risk of

101 onward transmission to other patients and healthcare workers. Infection control and prevention

102 efforts need to be enhanced around these patients to prevent further transmissions and studies

103 assessing the effectiveness of these policies are needed.

104 


\section{Introduction}

107 Nosocomial transmission and outbreaks of SARS-CoV-2 have been frequently reported in

108 various healthcare settings since the beginning of the pandemic. [1-6] Reported proportions of

109 hospitalised COVID-19 patients suspected to have acquired SARS-CoV-2 in the hospitals vary

110 widely, ranging from $<1 \%$ to $20 \%$, [7-10] and a national data linkage study in England

111 estimated that $15 \%$ of laboratory-confirmed cases among hospital patients were healthcare-

112 associated. [11]

114 Nosocomial transmission of SARS-CoV-2 is of considerable concern. Hospitalised patients are

115 especially vulnerable to COVID-19 associated complications and mortality. [2] Infected patients

116 who are asymptomatic or become symptomatic after discharge from the hospital may contribute

117 to the further spread of SARSCoV-2 in the community and nursing homes. Healthcare workers

$118(\mathrm{HCW})$ are disproportionately infected with SARS-CoV-2. [12-15] They may be a key source of

119 viral transmission to patients and fellow colleagues. Reduced staff workforce due to SARS-CoV-

1202 infection may compromise the clinical management of patients and infection prevention and

121 control measures. These threats remain relevant despite the introduction of vaccines as novel

122 variants can reduce the protection afforded, and their efficacy preventing onward transmissions

123 may only be partial.

125 Analysis of detailed individual-level data including information on patients at risk of becoming

126 infected has been lacking and the relative importance of different transmission pathways (e.g. 
medRxiv preprint doi: https://doi.org/10.1101/2021.04.28.21256245; this version posted May 1, 2021. The copyright holder for this preprint (which was not certified by peer review) is the author/funder, who has granted medRxiv a license to display the preprint in perpetuity.

It is made available under a CC-BY-NC-ND 4.0 International license .

127 patient to $\mathrm{HCW}, \mathrm{HCW}$ to patient, $\mathrm{HCW}$ to $\mathrm{HCW}$ and patient to patient) and has not, to our

128 knowledge, previously been quantified. [16] Improved understanding of the drivers of

129 nosocomial SARS-CoV2 infection is of potential value for improving targeting of infection

130 prevention and control activities in hospitals.

131

132 The objectives of this analysis are to use high resolution individual-level data to quantify

133 associations between patient characteristics and risks for acquiring nosocomial SARS-CoV-2

134 infection after adjusting for exposures, describe how risk of acquisition changes both with

135 calendar time and over a patient's hospital stay, and provide evidence about the relative

136 importance of different transmission pathways for both patients and HCW.

138 Methods

139 Study cohort

140 Data were obtained from Oxford University Hospitals, a group of four teaching hospitals

141 (denoted hospital A-D) in Oxfordshire, UK from 12 January 2020 to 2 October 2020. Two of the

142 four hospital sites (hospitals A and C) have an Emergency Department, and admitted

143 symptomatic SARS-CoV-2 patients directly from the community. Patient data included patient

144 demographics, location in the hospital on every day of stay, total length of stay, and SARS-CoV-

1452 PCR test results (supplementary section 7 for details of PCR assays).

147 SARS-CoV-2 infections in hospital HCW were identified using PCR results from symptomatic

148 and asymptomatic testing at the hospital. Symptomatic testing was offered to staff from 27 
149 March 2020 onwards and staff could participate in a voluntary asymptomatic screening

150 programme from 23 April 2020 onwards, offering testing up to once every two weeks.

151 Additionally, probable infections prior to widespread availability of testing were identified in

152 staff without a positive PCR result, but who were either anti-nucleocapsid or anti-spike IgG

153 antibody positive and recalled a date of onset of symptoms consistent with COVID-19. These

154 symptoms were the presence of fever and new persistent cough, or anosmia or loss of taste. [17,

155 18] Hospital HCW and patients who were on the same wards during the study period were

156 included in the analysis.

158 Data were classified as time-fixed and time-varying variables. Time-fixed variables included age

159 at admission, sex and ethnicity routinely collected in hospital records. Time-varying variables

160 included patients' ward and hospital location, and the number of other patients and HCW known

161 to be infected (and likely infectious) present on the same ward while a patient was at risk of

162 becoming infected with SARS-CoV-2.

164 Deidentified patient data and data from HCW testing were obtained from electronic healthcare

165 records using the Infections in Oxfordshire Research Database (IORD) which has generic

166 Research Ethics Committee, Health Research Authority and Confidentiality Advisory Group

167 approvals (19/SC/0403, 19/CAG/0144). 
medRxiv preprint doi: https://doi.org/10.1101/2021.04.28.21256245; this version posted May 1, 2021. The copyright holder for this preprint (which was not certified by peer review) is the author/funder, who has granted medRxiv a license to display the preprint in perpetuity.

It is made available under a CC-BY-NC-ND 4.0 International license .

\section{Definitions and assumptions}

\section{Incubation period}

171 We assumed that each individual could only be infected once, and hence patients and HCW were

172 no longer at risk for acquiring SARS-CoV-2 after their first positive PCR test. The day each

173 patient with a potential nosocomial infection became infected is unknown, but based on

174 knowledge of the incubation period distribution we expect it to be one to 20 days prior to the

175 date of symptom onset, with 83\% falling between 3-7 days. [19] For a given incubation period,

$176 d$, we assume that each patient with a nosocomial infection became infected $d$ days before the

177 date of symptom onset.

178

179 Among 245 inpatients testing positive after developing SARS-CoV-2 symptoms during

180 hospitalisation, the mean interval between symptom onset and their swab for PCR-testing was

181 one day (interquartile range 1-3). Consequently, we assumed that swabs for SARS-CoV-2 PCR

182 tests after hospital admission were taken in response to COVID-19-like symptom onset one day

183 earlier or, in asymptomatic cases, the swabs were assumed to have been taken one day after the

184 incubation period. The date of each patient's first positive PCR test refers to the date the swab

185 was obtained, rather than tested if this differed (figure 1). 


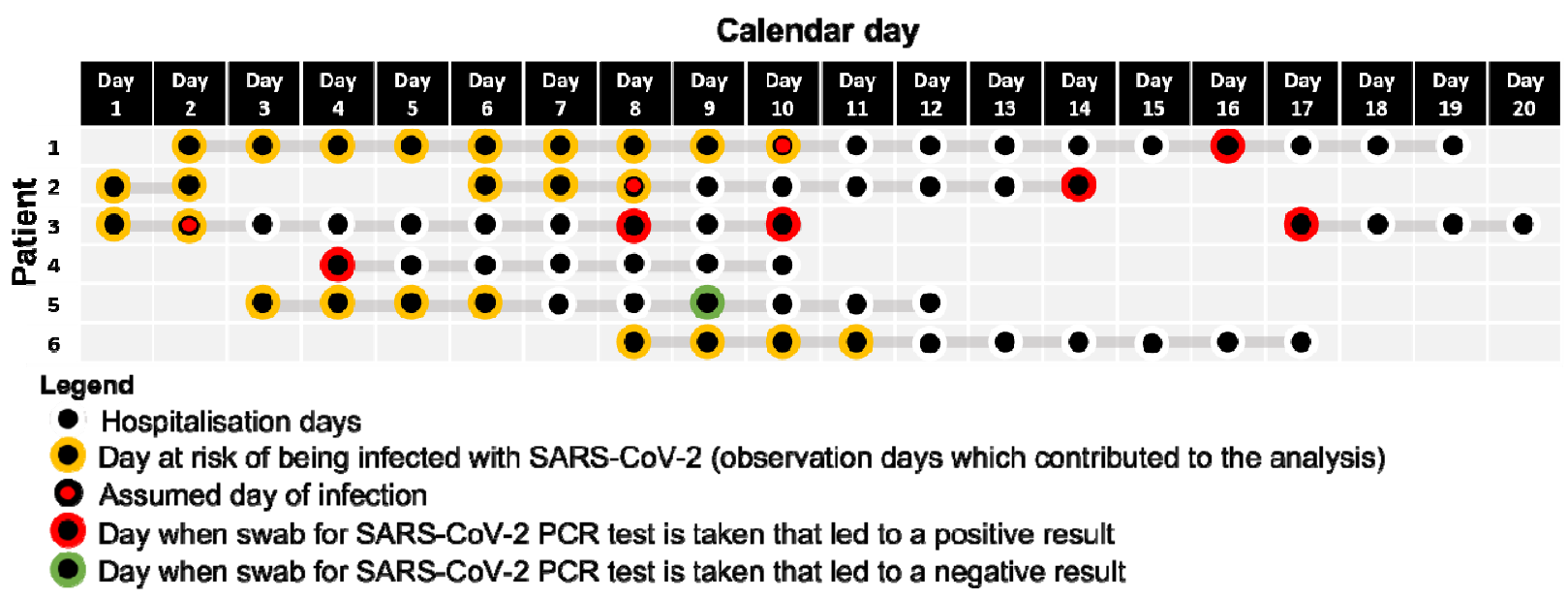

187 Figure 1: Illustration of assumed incubation periods and the data analysed for six example

188 patients. We assumed that PCR tests were performed one day after developing symptoms

189 consistent with COVID-19. In this schematic, an incubation period of five days was used. Each

190 hospitalised patient day from admission until (and including) the day of the assumed infection

191 event (i.e. six (incubation period plus one) days prior to the swab leading to the patient's first

192 positive PCR test) or six days prior to the day of discharge or death (whichever occurred first)

193 was considered an observation where the patient was at risk of becoming infected. Each

194 observation, unique to a specific patient on a specific day, therefore corresponds to an outcome

195 six days later when the patient could potentially have a swab taken for a SARS-CoV-2 PCR test.

196 An observation had a positive outcome (value of 1) if the patient had a positive PCR test for the

197 first time resulting from a swab taken in the hospital six days later, and a negative outcome

198 (value of 0) if the patient did not have a swab taken or had a swab taken resulting in a negative

199 PCR test six days later. The risk factors, e.g., ward, number of infectious patients or healthcare

200 workers in the same ward, for each observation were taken from the day of the observation itself

201 when the corresponding patient was at risk of becoming infected. 
medRxiv preprint doi: https://doi.org/10.1101/2021.04.28.21256245; this version posted May 1, 2021. The copyright holder for this preprint (which was not certified by peer review) is the author/funder, who has granted medRxiv a license to display the preprint in perpetuity.

It is made available under a CC-BY-NC-ND 4.0 International license .

\section{Definitions of nosocomial SARS-CoV-2 infections}

204 Nosocomial SARS-CoV-2 infections have previously been defined as 'probable' when

205 symptoms onset is on day 8-14 after admission and 'definite' when symptoms onset is on day

$206>14$ after admission. [20] These increasing thresholds correspond to higher certainties that a case

207 is hospital-acquired (supplementary figure S5). [20] In this study, however, we used incubation

208 periods that are the most likely to identify the exposure risk factors, i.e., the locations and

209 infectious individuals the susceptible individuals were exposed to, which could have resulted in

210 an observed infection event. Our baseline assumption was that the incubation period was five

211 days (which is reported to be the median value [20]), and we therefore define hospital-acquired

212 infections to be any PCR-confirmed SARS-CoV-2 infection where the patient was a hospital

213 inpatient six days prior to the first positive PCR test. We also report results for sensitivity

214 analyses assuming incubation periods of three and seven days. Community-acquired infections

215 are defined to be any PCR-confirmed infections in patients who were not hospitalised in the 20

216 days prior to their first positive PCR tests.

\section{Accounting for varying infectiousness}

219 We assumed that patients were infectious for a period of ten days starting a day after the day of

220 presumed infection, consistent with estimates that $99.7 \%$ of onward infection takes place within

221 the first ten days after the presumed infection event. [21, 26] HCW were assumed to be

222 infectious from a day after the day of assumed infection to the day of symptom onset or one day

223 prior to having a positive PCR test (i.e., staff were assumed to be absent from work after

224 reporting symptoms consistent with SARS-CoV-2 infection or having a positive PCR test). 
medRxiv preprint doi: https://doi.org/10.1101/2021.04.28.21256245; this version posted May 1, 2021. The copyright holder for this preprint (which was not certified by peer review) is the author/funder, who has granted medRxiv a license to display the preprint in perpetuity.

It is made available under a CC-BY-NC-ND 4.0 International license .

226 In the main analyses presented in the Results section, we considered infectiousness to be binary.

227 To account for time-varying infectiousness in relation to the time of presumed infection event,

228 we repeated the analysis after scaling the numbers of infectious patients and HCW in a ward on a

229 particular day by their relative infectiousness, using the generation time distribution derived by

230 Ferretti et al [21] such that the sum of daily terms for a single infected patient or HCW who was

231 present in the ward throughout their entire infectious period would equal one.

\section{Infection prevention and control measures}

234 There were two major changes made to infection prevention and control measures during the

235 study period. Prior to 1 April 2020 (phase 1) use of "level-1" personal protective equipment

236 (PPE; apron, gloves, a surgical face mask and optional eye protection) was recommended for

237 contact with patients known or suspected to have COVID-19 with use of "level-2" PPE (gown,

238 gloves, eye protection, FFP3/N99 mask) for aerosol generating procedures. From 1 April 2020

239 (phase 2) universal level-1 PPE was used for all patients regardless of test results or clinical

240 suspicion of COVID-19. From 25 April 2020 (phase 3), additionally, all patients were tested for

241 SARS-CoV-2 by PCR on admission and at weekly intervals irrespective of symptoms. Further

242 measures were implemented subsequently from June onwards, which include universal masking

243 and social distancing amongst staff, contact tracing and isolation of exposed patients and HCW,

244 establishment of COVID-19 dedicated areas, improved triage and recognition of atypical

245 symptoms in elderly patients. 
medRxiv preprint doi: https://doi.org/10.1101/2021.04.28.21256245; this version posted May 1, 2021. The copyright holder for this preprint (which was not certified by peer review) is the author/funder, who has granted medRxiv a license to display the preprint in perpetuity.

It is made available under a CC-BY-NC-ND 4.0 International license.

\section{Statistical models}

248 We first performed exploratory analyses using univariable and multivariable logistic regression

249 models to determine associations between risk factors and SARS-CoV-2 infection for given

250 incubation periods (supplementary section 6 code block 1). To assess how well these individual

251 demographic factors and infection pressures from infectious patients and healthcare workers on

252 the same wards accounted for the nosocomial SARS-CoV-2 infections over calendar time, we

253 used generalised additive models which allowed for the risk of infection to depend in a non-

254 linear manner on the predictors (supplementary section 6 code block 2) The generalised additive

255 models were implemented using the R package $m g c v$. [22]

257 We then modelled the patients' and HCW' daily risk of acquiring SARS-CoV-2 in the hospital

258 using a generalised linear mixed model with an identity link (supplementary section 6 code block

259 3). This model allowed the daily probability of infection to scale linearly with infection pressure

260 from HCW and patients and for their effects to be additive. These models were implemented

261 with JAGS (version 4-10) which uses Markov chain Monte Carlo to generate a sequence of

262 dependent samples from the posterior distribution of the parameters. [23]

264 Two versions of the models, one with interaction terms between the phases and forces of

265 infection from patients and $\mathrm{HCW}$, and one without the interaction terms, were performed. Model

266 comparison was done using the Widely Applicable Information Criterion (WAIC) where lower

267 values indicate improved model fit. [24] 
medRxiv preprint doi: https://doi.org/10.1101/2021.04.28.21256245; this version posted May 1, 2021. The copyright holder for this preprint (which was not certified by peer review) is the author/funder, who has granted medRxiv a license to display the preprint in perpetuity.

It is made available under a CC-BY-NC-ND 4.0 International license .

269 All analysis was performed in R version 4.0.2. [25] The corresponding analysis code for the

270 above models can be found in the supplementary material.

271

\section{Role of the funding source}

273 The funders had no role in study design, data collection and analysis, decision to publish, or

274 preparation of the manuscript. The views expressed in this publication are those of the authors

275 and not necessarily those of the UK National Health Service, the National Institute for Health

276 Research, the Department of Health or Public Health England, and other funders. All authors

277 confirm that we had full access to all the data in the study and accept responsibility to submit for

278 publication.

279

280 Results

\section{Patient characteristics}

282 There were 66,184 patients admitted to the four hospitals from 12 January to 2 October, 2020, a

283 time period that covered only the first 'wave' of infection in the UK. Amongst these patients, 920

$284(920 / 66,184,1 \%)$ had a positive SARS-CoV-2 PCR test. Out of these, 571 patients had their first

285 positive PCR tests while hospitalised (62\%), and 97 were on admission day seven or later (11\%).

286 The patient characteristics are shown in Table 1. The patients who likely acquired SARS-CoV-2

287 while in hospital (assuming incubation periods of 5, 3 or 7 days) were older, had longer lengths

288 of stays and more readmissions compared to patients with no positive SARS-CoV-2 PCR tests. 
medRxiv preprint doi: https://doi.org/10.1101/2021.04.28.21256245; this version posted May 1, 2021. The copyright holder for this preprint (which was not certified by peer review) is the author/funder, who has granted medRxiv a license to display the preprint in perpetuity.

\begin{tabular}{|c|c|c|c|c|c|c|}
\hline & & & $\begin{array}{r}\text { ents testing p } \\
\qquad(\mathrm{n}=\end{array}$ & for SARS-Co & & \multirow[t]{2}{*}{$\begin{array}{c}\text { Patients } \\
\text { did not } \\
\text { test } \\
\text { positive } \\
\text { for } \\
\text { SARS- } \\
\text { CoV-2 } \\
(n= \\
\text { 65264) }\end{array}$} \\
\hline & & $\begin{array}{c}\text { All } \\
\text { patients } \\
\text { tested } \\
\text { positive } \\
(\mathrm{n}=920)\end{array}$ & $\begin{array}{l}\text { Hospital- } \\
\text { acquired } \\
\text { infection } \\
\text { (assuming } \\
\quad \text { an } \\
\text { incubation } \\
\text { period of } 3 \\
\text { days) } \\
(\mathbf{n}=\mathbf{1 3 3})\end{array}$ & $\begin{array}{l}\text { Hospital- } \\
\text { acquired } \\
\text { infection } \\
\text { (assuming } \\
\quad \text { an } \\
\text { incubation } \\
\text { period of } 5 \\
\text { days) } \\
(n=130)\end{array}$ & $\begin{array}{l}\text { Hospital- } \\
\text { acquired } \\
\text { infection } \\
\text { (assuming } \\
\quad \text { an } \\
\text { incubation } \\
\text { period of } 7 \\
\text { days) } \\
(\mathbf{n}=120)\end{array}$ & \\
\hline $\begin{array}{l}\text { Age (mean age in } \\
\text { years, sd) }\end{array}$ & & $67.9(20.7)$ & $75.8(17.3)$ & 76.9 (16.4) & $76.6(16.6)$ & $\begin{array}{c}49.1 \\
(27.3)\end{array}$ \\
\hline \multirow[t]{2}{*}{$\operatorname{Sex}(n, \%)$} & Female & $453(49 \%)$ & $70(53 \%)$ & $66(51 \%)$ & $65(54 \%)$ & $\begin{array}{l}34887 \\
(53 \%)\end{array}$ \\
\hline & Male & $467(51 \%)$ & $63(47 \%)$ & $64(49 \%)$ & $55(46 \%)$ & $\begin{array}{l}30350 \\
(47 \%)\end{array}$ \\
\hline \multirow[t]{3}{*}{$\begin{array}{l}\text { Ethnic groups (n, } \\
\%)\end{array}$} & White & $630(68 \%)$ & $107(80 \%)$ & $105(81 \%)$ & $100(83 \%)$ & $\begin{array}{l}46942 \\
(72 \%)\end{array}$ \\
\hline & Non-white & $111(12 \%)$ & $0(0 \%)$ & $2(2 \%)$ & $2(2 \%)$ & $\begin{array}{l}5122 \\
(8 \%)\end{array}$ \\
\hline & Unknown & $179(19 \%)$ & $26(20 \%)$ & $23(18 \%)$ & $18(15 \%)$ & $\begin{array}{l}13163 \\
(20 \%)\end{array}$ \\
\hline $\begin{array}{l}\text { Total } \\
\text { hospitalisation } \\
\text { days from } \\
\text { Jan to Oct } 2020 \\
\text { (mean, sd) }\end{array}$ & & $17.8(22.2)$ & $38.6(32.2)$ & $41.3(32.5)$ & $42.1(33.0)$ & $5.8(11.8)$ \\
\hline $\begin{array}{l}\text { Total } \\
\text { number of } \\
\text { admissions } \\
\text { from Jan to } \\
\text { Oct 2020 } \\
\text { (mean, sd) }\end{array}$ & & $1.7(1.2)$ & $1.9(1.5)$ & $2.0(1.5)$ & $2(1.5)$ & $1.4(1.2)$ \\
\hline \multirow[t]{4}{*}{$\begin{array}{l}\text { Admission } \\
\text { days to each } \\
\text { hospital from } \\
\text { Jan to Oct } 2020 \\
(n, \%)\end{array}$} & Hospital A & $855(5 \%)$ & $248(5 \%)$ & $279(5 \%)$ & $284(6 \%)$ & $\begin{array}{l}57868 \\
(15 \%)\end{array}$ \\
\hline & Hospital B & $\begin{array}{c}2846 \\
(17 \%)\end{array}$ & $959(19 \%)$ & $1121(21 \%)$ & $1076(21 \%)$ & $\begin{array}{l}37358 \\
(10 \%)\end{array}$ \\
\hline & Hospital C & $\begin{array}{l}11417 \\
(70 \%)\end{array}$ & $3287(64 \%)$ & $3238(60 \%)$ & $3041(60 \%)$ & $\begin{array}{c}260247 \\
(69 \%)\end{array}$ \\
\hline & Hospital D & $1279(8 \%)$ & $634(12 \%)$ & $731(14 \%)$ & $653(13 \%)$ & $\begin{array}{c}23226 \\
(6 \%)\end{array}$ \\
\hline $\begin{array}{l}\text { Number of } \\
\text { SARS-CoV-2 }\end{array}$ & & $2.7(2.7)$ & $3.5(3.2)$ & $3.8(3.4)$ & $3.8(3.4)$ & $0.9(1.7)$ \\
\hline
\end{tabular}


medRxiv preprint doi: https://doi.org/10.1101/2021.04.28.21256245; this version posted May 1, 2021. The copyright holder for this preprint (which was not certified by peer review) is the author/funder, who has granted medRxiv a license to display the preprint in perpetuity.

It is made available under a CC-BY-NC-ND 4.0 International license .

\begin{tabular}{|c|c|c|c|c|c|c|}
\hline $\begin{array}{l}\text { PCR tests per } \\
\text { patient } \\
(\text { mean, sd) }\end{array}$ & & & & & & \\
\hline \multirow{2}{*}{$\begin{array}{l}\text { Admission days } \\
\text { to each ward } \\
\text { type during } \\
\text { infectious } \\
\text { period }^{\$}\end{array}$} & General & 3283 & $1234(97 \%)$ & $1121(97 \%)$ & $946(97 \%)$ & \\
\hline & $\begin{array}{l}\text { ICU/ } \\
\text { HDU* }\end{array}$ & $471(13 \%)$ & $42(3 \%)$ & $36(3 \%)$ & $34(3 \%)$ & \\
\hline \multirow{2}{*}{$\begin{array}{l}\text { Admission days } \\
\text { to each ward } \\
\text { type during at- } \\
\text { risk period }^{+}\end{array}$} & $\begin{array}{l}\text { General } \\
\text { Ward }\end{array}$ & $\begin{array}{c}4737 \\
(96 \%)\end{array}$ & $1924(95 \%)$ & $2254(95 \%)$ & $2252(95 \%)$ & $\begin{array}{c}134001 \\
(92 \%)\end{array}$ \\
\hline & $\begin{array}{l}\text { ICU/ } \\
\text { HDU* }\end{array}$ & $178(4 \%)$ & $100(5 \%)$ & $125(5 \%)$ & $122(5 \%)$ & $\begin{array}{c}11968 \\
(8 \%)\end{array}$ \\
\hline $\begin{array}{l}\text { At-risk days } \\
\text { per patient } \\
\text { (mean, sd) }\end{array}$ & & $5.3(11.5)$ & $15.2(17.3)$ & $18.3(18.1)$ & $19.8(17.8)$ & $2.2(10.3)$ \\
\hline
\end{tabular}

${ }^{\#}$ All patients included in the table had at least one day of inpatient stay during the observation period between 12 January and 2 October 2020.

${ }^{*}$ ICU/ HDU: Intensive care units/ High-dependency units

${ }^{\$}$ Infectious period: Patients were considered infectious from the day after infection to ten days after

294 infection. [21]

${ }^{+}$At-risk period: Patients were considered to be at risk of being infected with SARS-CoV-2 from admission to either discharge/ death or four, six or eight days before their first positive PCR tests, i.e., day of presumed infection.

Table 1: Characteristics of the patients included in the analysis.

Testing capacity increased substantially after the beginning of March 2020 (figure 2A). The weekly incidence of newly detected SARS-CoV-2 infections in the four hospitals, including both community-acquired and nosocomial cases, peaked between March and May 2020. to being tested positive for SARS-CoV-2. Out of these patients, $130(48 \%)$ were inpatients on their day of infection, based on an assumed incubation period of five days. One-hundred and two 
medRxiv preprint doi: https://doi.org/10.1101/2021.04.28.21256245; this version posted May 1, 2021. The copyright holder for this preprint (which was not certified by peer review) is the author/funder, who has granted medRxiv a license to display the preprint in perpetuity.

It is made available under a CC-BY-NC-ND 4.0 International license .

309 (79\%). The median length of stay for the admissions during which the patients were infected

310 with SARS-CoV-2 was 21 days (interquartile range 13 to 35 days). The median day of

311 hospitalisation when these patients were assumed to have been infected was day 8 (interquartile

312 range 3 to 18 days).

313

A

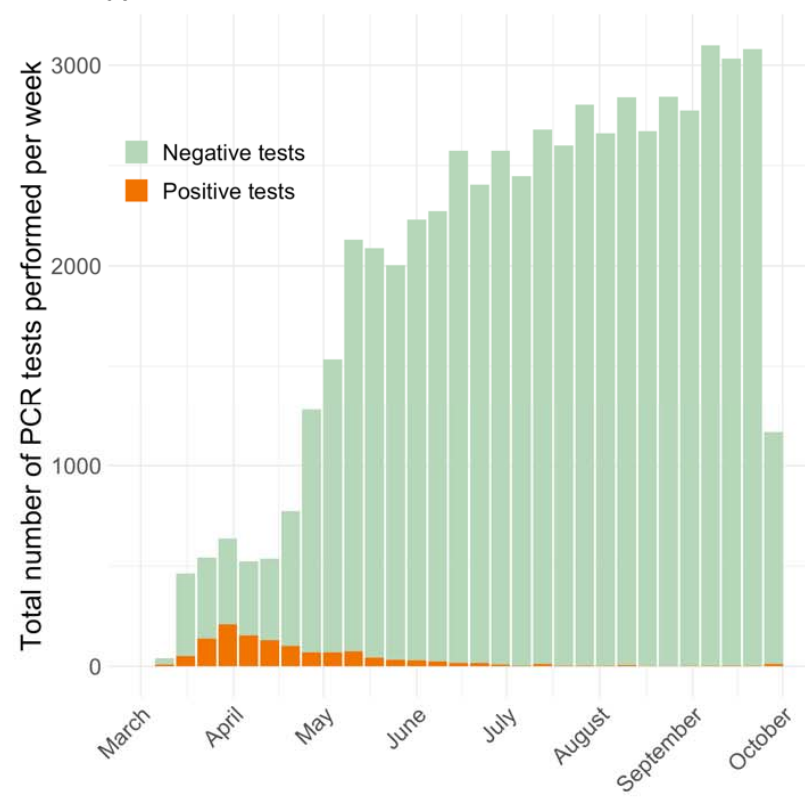

314

Figure 2: Weekly sums of SARS-CoV-2 PCR tests performed during March to October 2020

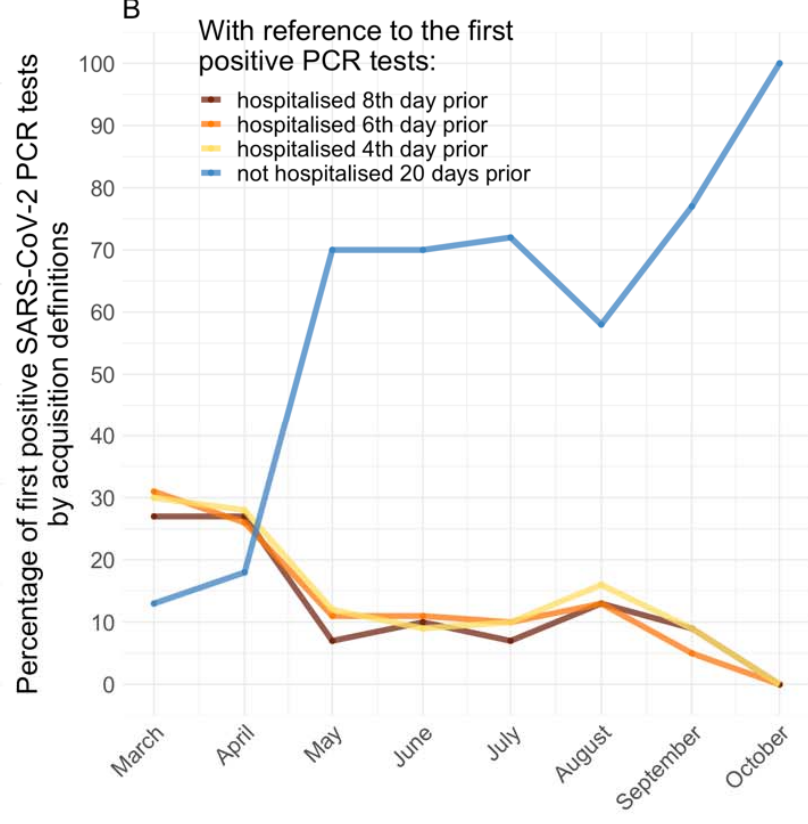

(Panel A). The stacked green bars indicate the number of negative tests. The stacked orange bars indicate the number of positive tests. Percentage of first positive SARS-CoV-2 PCR tests classified by different types of acquisition (Panel B). The colours represent patients who were inpatients on the eighth (red), sixth (orange), and forth day (yellow) prior to their first positive tests, and who were not hospitalised in the 20 days prior to their first positive tests (blue). These classifications are not mutually exclusive, e.g., a patient who was admitted for ten days continuously prior to the first positive PCR test would contribute to all first three groups. 
medRxiv preprint doi: https://doi.org/10.1101/2021.04.28.21256245; this version posted May 1, 2021. The copyright holder for this preprint (which was not certified by peer review) is the author/funder, who has granted medRxiv a license to display the preprint in perpetuity.

It is made available under a CC-BY-NC-ND 4.0 International license .

\section{Healthcare worker characteristics}

326 Out of a total of $13,514 \mathrm{HCW}$ in the four hospitals participating in HCW testing at some time,

3275,596 worked on a single ward only such that their SARS-CoV-2 status could be considered with 328 patients admitted to the same wards in the analysis. Eleven percent (615/5596) were positive for

329 SARS-CoV-2 during the study period. Amongst those who were positive, 57\% (353/615) had a 330 positive PCR test, while the rest were diagnosed based on serology.

\begin{tabular}{|c|c|c|c|}
\hline & & $\begin{array}{c}\text { Positive for SARS-CoV-2 } \\
n=615\end{array}$ & $\begin{array}{l}\text { Negative for SARS-CoV-2 } \\
\qquad n=4981\end{array}$ \\
\hline $\begin{array}{l}\text { Age (mean age in } \\
\text { years, } s d)\end{array}$ & & $39.5(11.1)$ & $39.6(11.7)$ \\
\hline \multirow[t]{2}{*}{$\operatorname{Sex}(n, \%)$} & Female & $485(79 \%)$ & $3902(78 \%)$ \\
\hline & Male & $130(21 \%)$ & $1079(22 \%)$ \\
\hline \multirow[t]{4}{*}{ Roles (n, \%) } & Doctor & $98(16 \%)$ & $955(19 \%)$ \\
\hline & Nurses & $306(50 \%)$ & $1984(40 \%)$ \\
\hline & $\begin{array}{l}\text { Allied } \\
\text { health }\end{array}$ & $136(22 \%)$ & $1274(26 \%)$ \\
\hline & $\begin{array}{l}\text { Non- } \\
\text { clinical } \\
\text { staff }\end{array}$ & $75(12 \%)$ & $768(15 \%)$ \\
\hline \multirow{4}{*}{$\begin{array}{l}\text { Hospital worked in } \\
\text { during the } \\
\text { observation period } \\
(n, \%)\end{array}$} & Hospital A & $97(16 \%)$ & $972(20 \%)$ \\
\hline & Hospital B & $91(15 \%)$ & $454(9 \%)$ \\
\hline & Hospital C & $379(62 \%)$ & $3276(66 \%)$ \\
\hline & Hospital D & $48(8 \%)$ & $279(6 \%)$ \\
\hline \multirow{2}{*}{$\begin{array}{l}\text { Ward type worked } \\
\text { in during the } \\
\text { observation period } \\
(n, \%)\end{array}$} & $\begin{array}{l}\text { General } \\
\text { Ward }\end{array}$ & $569(93 \%)$ & $4384(88 \%)$ \\
\hline & $\begin{array}{l}\text { ICU/ } \\
\text { HDU* }^{*}\end{array}$ & $46(7 \%)$ & $597(12 \%)$ \\
\hline
\end{tabular}


medRxiv preprint doi: https://doi.org/10.1101/2021.04.28.21256245; this version posted May 1, 2021. The copyright holder for this preprint (which was not certified by peer review) is the author/funder, who has granted medRxiv a license to display the preprint in perpetuity.

It is made available under a CC-BY-NC-ND 4.0 International license .

* ICU/ HDU: Intensive care units/ High-dependency units

Table 2: Characteristics of the healthcare workers included in the analysis.

336 The timelines of the numbers of susceptible patients and infectious patients and HCW on each

337 ward showed that most of the peaks in the number of potential transmission events occurred

338 between March and June 2020 (figure S1). On most wards there was considerable overlap

339 between the time series for infectious HCW and patients and the time series of transmission

340 events.

\section{Transmission risk to patients}

343 We first used multivariable logistic regression to identify the factors associated with nosocomial

344 transmission of SARS-CoV-2 to susceptible patients (table 3). Infection risk reduced with the

345 introduction of more stringent infection prevention and control measures in phase three (adjusted

346 odds ratio, aOR $0.25,95 \%$ CI $0.14,0.42$ ). Presence of patients with hospital-acquired SARS-

347 CoV-2 was associated with the highest risk of acquisition in susceptible patients (aOR, 1.76,

$34895 \%$ CI 1.51, 2.04), followed by the presence of infected HCW (aOR 1.45, 95\%CI 1.22,1.71).

349 The evidence that patients with community onset COVID-19 were associated with increased

350 transmission was weaker (aOR 1.12, 95\%CI 0.96,1.26).

\begin{tabular}{|c|c|c|c|c|c|c|c|c|c|}
\hline \multirow{3}{*}{ Characteristics } & & \multicolumn{8}{|c|}{ Incubation period } \\
\hline & \multicolumn{3}{|c|}{5 days } & \multicolumn{3}{|c|}{3 days } & \multicolumn{3}{|c|}{7 days } \\
\hline & $\mathbf{O R}^{1}$ & $\begin{array}{c}95 \% \\
\text { CI }^{1}\end{array}$ & $\begin{array}{c}\text { p- } \\
\text { value }\end{array}$ & $\mathbf{O R}^{1}$ & $\begin{array}{r}95 \% \\
\text { CI }^{1}\end{array}$ & $\begin{array}{c}\text { p- } \\
\text { value }\end{array}$ & $\mathbf{O R}^{1}$ & $\begin{array}{r}95 \% \\
\text { CI }^{1}\end{array}$ & $\begin{array}{c}\text { p- } \\
\text { value }\end{array}$ \\
\hline
\end{tabular}




\begin{tabular}{|c|c|c|c|c|c|c|c|c|c|}
\hline Age & 1.03 & $\begin{array}{l}1.01 \\
1.04\end{array}$ & $\begin{array}{l}<0.00 \\
1\end{array}$ & 1.02 & $\begin{array}{l}1.01 \\
1.04\end{array}$ & $\begin{array}{l}<0.00 \\
1\end{array}$ & 1.02 & $\begin{array}{l}1.01 \\
1.04\end{array}$ & $\begin{array}{l}<0.00 \\
1\end{array}$ \\
\hline \multicolumn{10}{|l|}{ Sex } \\
\hline Female & - & - & & - & - & & - & - & \\
\hline Male & 1.03 & $\begin{array}{l}0.69 \\
1.52\end{array}$ & 0.90 & 0.97 & $\begin{array}{l}0.64 \\
1.44\end{array}$ & 0.90 & 1.02 & $\begin{array}{l}0.68 \\
1.54\end{array}$ & 0.91 \\
\hline \multicolumn{10}{|l|}{ Ethnic group } \\
\hline White & - & - & & - & - & & - & - & \\
\hline Non-white & 0.49 & $\begin{array}{l}0.08 \\
1.61\end{array}$ & 0.30 & 0.00 & $\begin{array}{l}0.00 \\
0.29\end{array}$ & 0.97 & 0.52 & $\begin{array}{l}0.08 \\
1.71\end{array}$ & 0.40 \\
\hline $\begin{array}{l}\text { Infectious patients } \\
\text { with community- } \\
\text { acquired SARS- } \\
\text { CoV-2 on the same } \\
\text { ward }\end{array}$ & 1.12 & $\begin{array}{l}0.96 \\
1.26\end{array}$ & 0.10 & 1.04 & $\begin{array}{l}0.89 \\
1.18\end{array}$ & 0.60 & 1.27 & $\begin{array}{l}1.08 \\
1.44\end{array}$ & $\begin{array}{l}<0.00 \\
1\end{array}$ \\
\hline $\begin{array}{l}\text { Infectious } \\
\text { patients with } \\
\text { hospital- } \\
\text { acquired SARS- } \\
\text { CoV-2 on the } \\
\text { same ward }\end{array}$ & 1.76 & $\begin{array}{l}1.51 \\
2.04\end{array}$ & $\begin{array}{l}<0.00 \\
1\end{array}$ & 1.94 & $\begin{array}{l}1.64 \\
2.28\end{array}$ & $\begin{array}{l}<0.00 \\
1\end{array}$ & 1.62 & $\begin{array}{l}1.35 \\
1.91\end{array}$ & $\begin{array}{l}<0.00 \\
1\end{array}$ \\
\hline $\begin{array}{l}\text { Infectious staff on } \\
\text { the same ward }\end{array}$ & 1.45 & $\begin{array}{l}1.22 \\
1.71\end{array}$ & $\begin{array}{l}<0.00 \\
1\end{array}$ & 1.55 & $\begin{array}{l}1.21 \\
1.94\end{array}$ & $\begin{array}{l}<0.00 \\
1\end{array}$ & 1.46 & $\begin{array}{l}1.27 \\
1.67\end{array}$ & $\begin{array}{l}<0.00 \\
1\end{array}$ \\
\hline \multicolumn{10}{|l|}{ Hospital } \\
\hline Hospital A & - & - & & - & - & & - & - & \\
\hline Hospital B & 2.06 & $\begin{array}{l}0.87 \\
5.70\end{array}$ & 0.13 & 2.58 & $\begin{array}{l}1.02 \\
7.87\end{array}$ & 0.06 & 3.22 & $\begin{array}{l}1.22 \\
11.1\end{array}$ & 0.03 \\
\hline Hospital C & 1.65 & $\begin{array}{l}0.75 \\
4.33\end{array}$ & 0.30 & 2.01 & $\begin{array}{l}0.87 \\
5.85\end{array}$ & 0.14 & 2.37 & $\begin{array}{l}0.95 \\
7.92\end{array}$ & 0.10 \\
\hline Hospital D & 3.06 & $\begin{array}{l}1.26 \\
8.58\end{array}$ & 0.02 & 3.94 & $\begin{array}{l}1.54 \\
12.1\end{array}$ & 0.01 & 3.96 & $\begin{array}{l}1.39 \\
14.1\end{array}$ & 0.01 \\
\hline \multicolumn{10}{|l|}{ Type of ward } \\
\hline General Ward & - & - & & - & - & & - & - & \\
\hline ICU/ HDU ${ }^{2}$ & 0.62 & $\begin{array}{l}0.15 \\
1.68\end{array}$ & 0.40 & 0.45 & $\begin{array}{l}0.07 \\
1.44\end{array}$ & 0.30 & 0.20 & $\begin{array}{l}0.01 \\
0.90\end{array}$ & 0.11 \\
\hline Day of stay & 1.00 & $\begin{array}{l}0.99 \\
1.01\end{array}$ & 0.70 & 1.00 & $\begin{array}{l}0.99 \\
1.01\end{array}$ & 0.98 & 0.99 & $\begin{array}{l}0.98 \\
1.00\end{array}$ & 0.10 \\
\hline \multicolumn{10}{|l|}{ Phases $^{3}$} \\
\hline 1 & - & - & & - & - & & - & - & \\
\hline 2 & 2.06 & $\begin{array}{l}1.15 \\
3.62\end{array}$ & 0.013 & 2.80 & $\begin{array}{l}1.55 \\
4.98\end{array}$ & 0.001 & 1.30 & $\begin{array}{l}0.69 \\
2.38\end{array}$ & 0.40 \\
\hline 3 & 0.25 & $\begin{array}{l}0.14 \\
0.42\end{array}$ & $\begin{array}{l}<0.00 \\
1\end{array}$ & 0.27 & $\begin{array}{l}0.16 \\
0.46\end{array}$ & 0.002 & 0.30 & $\begin{array}{l}0.18 \\
0.50\end{array}$ & $\begin{array}{l}<0.00 \\
1\end{array}$ \\
\hline
\end{tabular}

${ }^{1} \mathrm{OR}=$ Odds Ratio, $\mathrm{CI}=$ Confidence Interval

$353{ }^{2}$ ICU/ HDU = Intensive care units/ High dependency units 
$354{ }^{3}$ In addition to phases, calendar days was included as a non-linear independent variable in the logistic 355 regression, fitted with a linear spline function with two knots.

357 Table 3: Predictors of SARS-CoV-2 infection in admitted patients during their hospital stay from 358 multivariable logistic regression results.

360 To further investigate if the demographic variables and transmissions from infectious patients

361 and HCW adequately accounted for patient acquisition of SARS-CoV-2, we used these variables

362 in a generalised additive model (supplementary section 3.1 model $P 2$ ). After adjusting for these

363 variables, the results showed that the variation in the risk of nosocomial infection over the study

364 period remained though at a reduced level, suggesting that transmission risks were incompletely

365 accounted for (figure 3 panel A). We further used the above generalised additive model to

366 explore how risk of nosocomial SARS-CoV-2 infection varied with day of hospitalisation

367 (supplementary figure S2). This risk remained largely constant throughout a patient's hospital

368 stay once the numbers of infectious patients and HCW in the same ward were accounted for. 
medRxiv preprint doi: https://doi.org/10.1101/2021.04.28.21256245; this version posted May 1, 2021. The copyright holder for this preprint (which was not certified by peer review) is the author/funder, who has granted medRxiv a license to display the preprint in perpetuity.

It is made available under a CC-BY-NC-ND 4.0 International license .

A. Daily SARS-CoV-2 transmission risk to susceptible patients
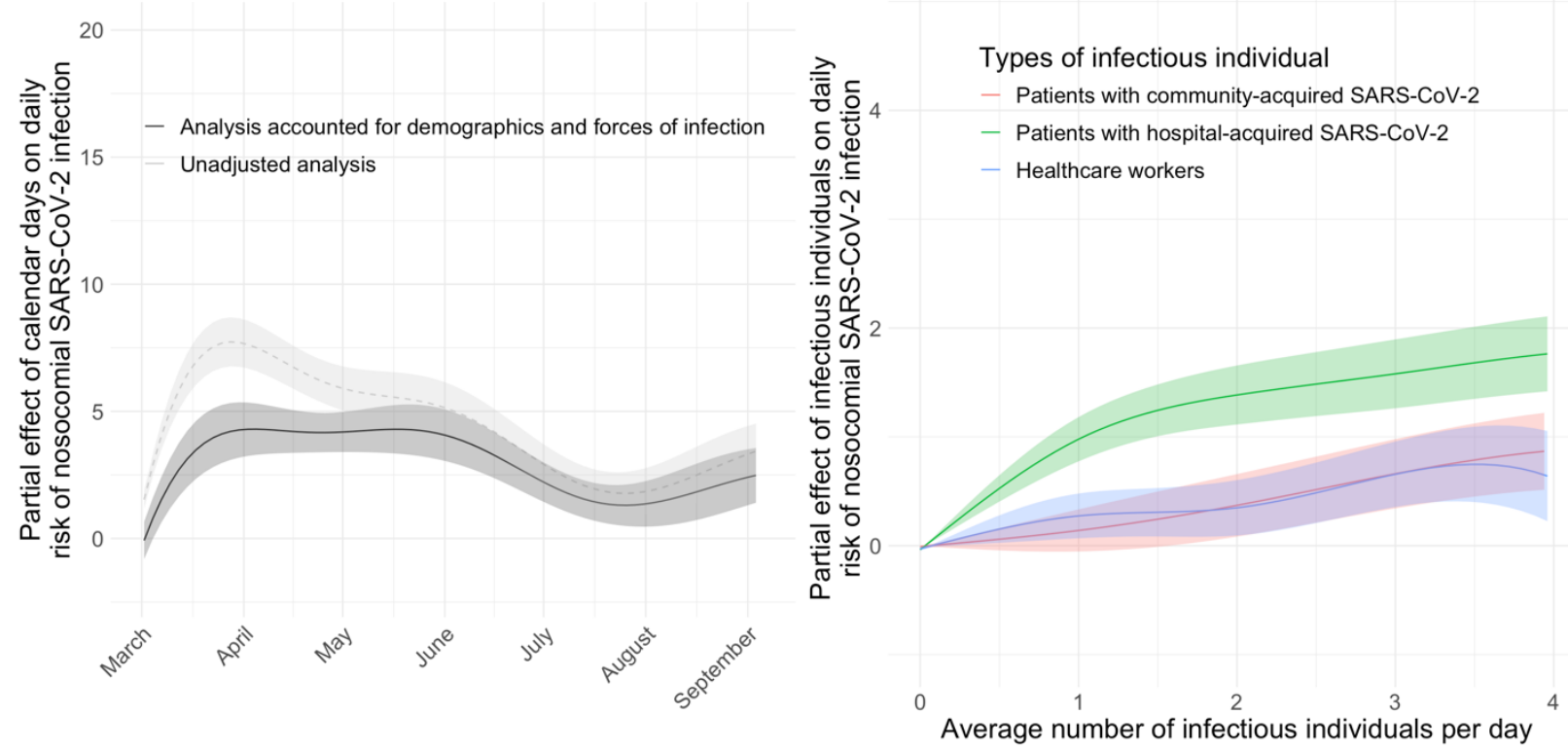

B. Daily SARS-CoV-2 transmission risk to susceptible healthcare staff
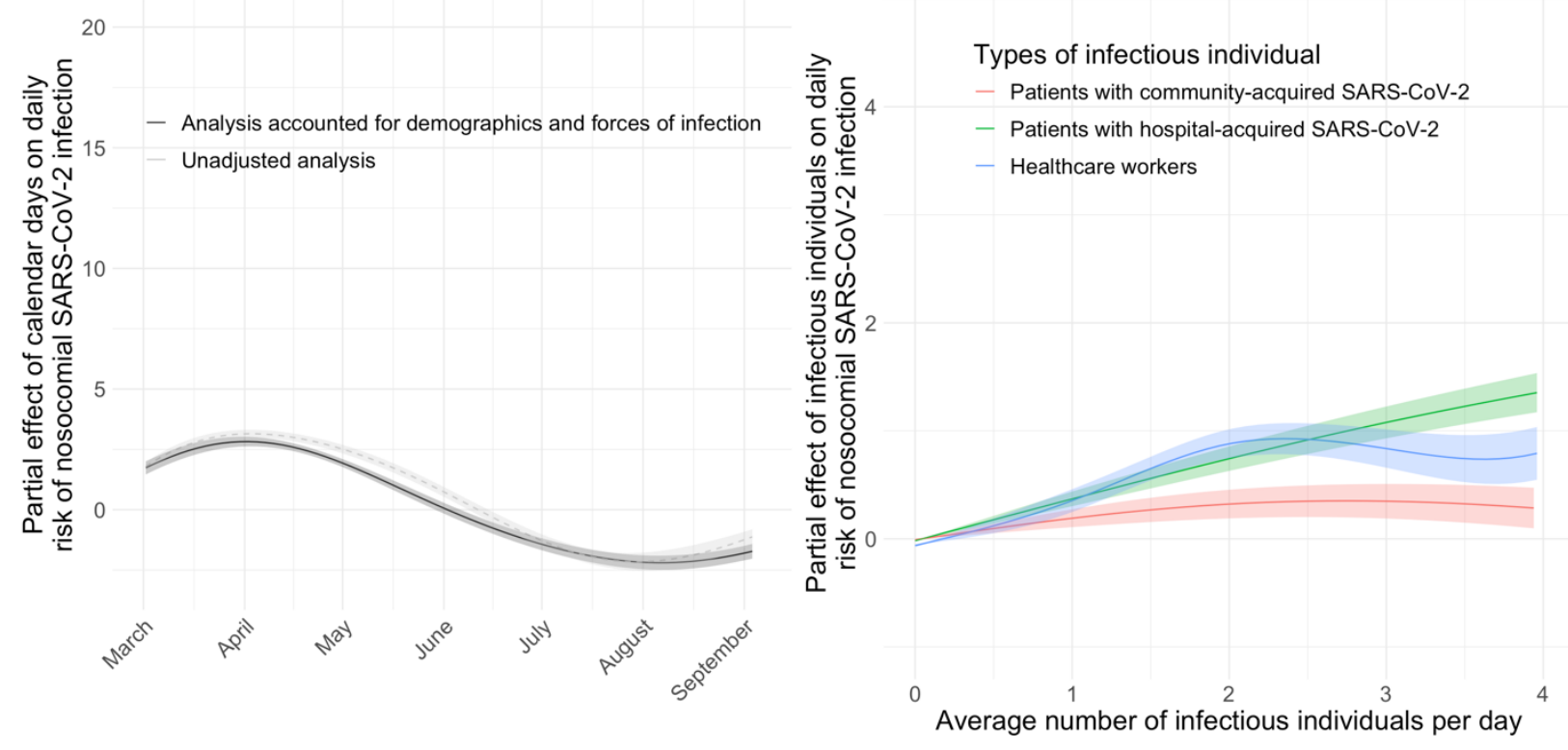

372 Figure 3. Daily transmission risk to susceptible patients (Panel A) and healthcare workers (Panel

373 B) using a generalised additive model with a logit link. The smooth, non-linear partial effects of

374 calendar day, infectious patients and healthcare workers on the daily risk of nosocomial SARS-

$375 \mathrm{CoV}-2$ infection are presented as coloured lines. These partial effects are the isolated effects of

376 each group of infectious individuals on the binary outcome of assumed acquisition (yes/no) on 
medRxiv preprint doi: https://doi.org/10.1101/2021.04.28.21256245; this version posted May 1, 2021. The copyright holder for this preprint (which was not certified by peer review) is the author/funder, who has granted medRxiv a license to display the preprint in perpetuity.

It is made available under a CC-BY-NC-ND 4.0 International license .

377 each day as the dependent variable. Infectious patients and healthcare workers were both

378 associated with increased risk of nosocomial infection. The presence of more infectious patients

379 or healthcare workers in a ward on a given day was associated with higher transmission risk.

381 A shortcoming of the logistic regression model is that it assumed the effect of each additional

382 infectious patient or HCW as multiplicative. Therefore, we used an alternative statistical model

383 that allows each extra infectious individual to increase the probability of infection in an additive

384 way (a generalised mixed model with an identity link). Infectious patients on the same ward who

385 were assumed to have hospital-acquired SARS-CoV-2 showed the strongest association with

386 acquisition of nosocomial COVID-19 in susceptible patients (figure 4). Using an assumed

387 incubation period of 5 days, the absolute risk of acquiring SARS-CoV-2 per day of exposure to a

388 patient with hospital-acquired SARS-CoV-2 infection was 0.75\% (95\% credible interval, CrI

$3890.55-0.95 \%)$. The risks of acquiring SARS-CoV-2 per day of exposure to an infectious patient

390 who acquired SARS-CoV-2 in the community or to an infectious HCW were smaller. One day

391 exposure to an infected HCW or patient with community-acquired COVID19 was associated

392 with absolute risks of $0.20 \%$ (95\% CrI 0.16-0.22\%) and $0.17 \%$ (95\% CrI 0.13-0.22\%) respectively

393 for susceptible patients. 
medRxiv preprint doi: https://doi.org/10.1101/2021.04.28.21256245; this version posted May 1, 2021. The copyright holder for this preprint (which was not certified by peer review) is the author/funder, who has granted medRxiv a license to display the preprint in perpetuity.

It is made available under a CC-BY-NC-ND 4.0 International license .

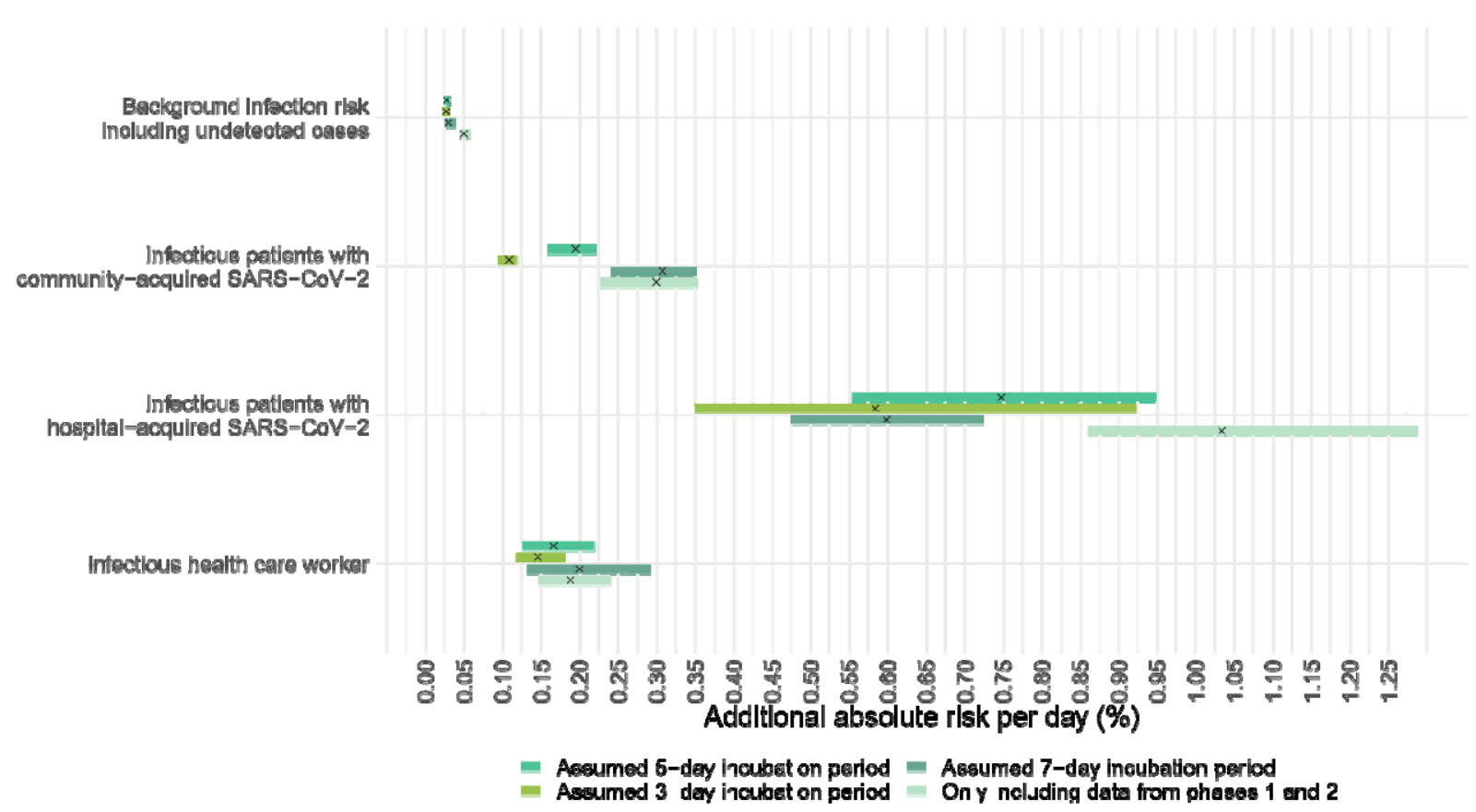

396 Figure 4: Additional risk of suspected nosocomial acquisition of SARS-CoV-2 experienced by a

397 single susceptible patient contributed by i) infectious patients who acquired SARS-CoV-2 in the

398 community (second row); ii) infectious patients who acquired SARS-CoV-2 in the hospital (third

399 row) and iii) infectious healthcare workers (last row). A generalised mixed model with an

400 identity link was used, with assumed nosocomial acquisition (yes/no) on each day as the

401 dependent variable. Both the intercepts and slopes were allowed to vary by ward. The top row

402 shows the variation of the intercepts of the model, which represent the background infection risk

403 posed by infectious patients and healthcare workers who are undetected. Each horizontal bar

404 represents the $95 \%$ credible interval of the estimate.

405

406 Transmission risk to healthcare workers

407 We performed similar analyses to quantify the risk of transmission to HCW. The multivariable

408 logistic regression results showed that nurses were at the highest risk of being infected with 
medRxiv preprint doi: https://doi.org/10.1101/2021.04.28.21256245; this version posted May 1, 2021. The copyright holder for this preprint (which was not certified by peer review) is the author/funder, who has granted medRxiv a license to display the preprint in perpetuity.

It is made available under a CC-BY-NC-ND 4.0 International license .

409 SARS-CoV-2 (aOR 1.58, 95\%CI 1.18, 2.07). Working in the intensive-care or high-dependency

410 units was protective against transmission (aOR 0.55, 95\%CI 0.39, 0.75). Transmission risk

411 reduced in phase three $(\mathrm{aOR} 0.43,95 \% \mathrm{CI} 0.34,0.53)$. The number of infectious $\mathrm{HCW}$ and

412 patients who had hospital-acquired SARS-CoV-2 on the same ward had the strongest

413 associations with transmission to HCW (aOR 1.66, 95\%CI 1.55,1.78 and aOR 1.45, 95\%CI

$4141.32,1.58$ respectively) (table 4).

415 
medRxiv preprint doi: https://doi.org/10.1101/2021.04.28.21256245; this version posted May 1, 2021. The copyright holder for this preprint (which was not certified by peer review) is the author/funder, who has granted medRxiv a license to display the preprint in perpetuity.

It is made available under a CC-BY-NC-ND 4.0 International license .

\begin{tabular}{|c|c|c|c|c|c|c|c|c|c|}
\hline \multirow{3}{*}{$\begin{array}{l}\text { Characteristics } \\
\end{array}$} & \multicolumn{9}{|c|}{ Incubation period } \\
\hline & \multicolumn{3}{|c|}{5 days } & \multicolumn{3}{|c|}{3 days } & \multicolumn{2}{|c|}{7 days } & \multirow[b]{2}{*}{ p-value } \\
\hline & $\mathbf{O R}^{1}$ & $\begin{array}{r}95 \% \\
\text { CI }^{1}\end{array}$ & p-value & $\mathbf{O R}^{1}$ & $\begin{array}{r}95 \% \\
\mathrm{CI}^{1}\end{array}$ & p-value & $\mathbf{O R}^{1}$ & $\begin{array}{r}95 \% \\
\text { CI }^{1}\end{array}$ & \\
\hline $\mathbf{A g e}^{2}$ & 1.00 & $\begin{array}{l}0.99 \\
1.01\end{array}$ & 0.80 & 1.00 & $\begin{array}{l}0.99 \\
1.01\end{array}$ & 0.8 & 1.00 & $\begin{array}{l}0.99, \\
1.01\end{array}$ & 0.92 \\
\hline \multicolumn{10}{|l|}{ Sex } \\
\hline Female & - & - & & - & - & & - & - & \\
\hline Male & 1.23 & $\begin{array}{l}0.97 \\
1.56\end{array}$ & 0.08 & 1.19 & $\begin{array}{l}0.93 \\
1.50\end{array}$ & 0.2 & 1.19 & $\begin{array}{l}0.93, \\
1.50\end{array}$ & 0.2 \\
\hline \multicolumn{10}{|l|}{ Role } \\
\hline Doctor & - & - & & - & - & & - & - & \\
\hline Nurse & 1.58 & $\begin{array}{l}1.18 \\
2.07\end{array}$ & 0.002 & 1.66 & $\begin{array}{l}1.26 \\
2.21\end{array}$ & $<0.001$ & 1.50 & $\begin{array}{l}1.15 \\
1.98\end{array}$ & 0.004 \\
\hline Allied health & 1.03 & $\begin{array}{l}0.76 \\
1.40\end{array}$ & 0.9 & 1.06 & $\begin{array}{l}0.78 \\
1.45\end{array}$ & 0.7 & 0.93 & $\begin{array}{l}0.68, \\
1.25\end{array}$ & 0.6 \\
\hline $\begin{array}{l}\text { Non-clinical } \\
\text { staff }\end{array}$ & 1.03 & $\begin{array}{l}0.72, \\
1.46\end{array}$ & 0.9 & 1.10 & $\begin{array}{l}0.77 \\
1.56\end{array}$ & 0.6 & 0.94 & $\begin{array}{l}0.66, \\
1.33\end{array}$ & 0.7 \\
\hline $\begin{array}{l}\text { Infectious } \\
\text { patients with } \\
\text { community- } \\
\text { acquired } \\
\text { SARS-CoV-2 } \\
\text { on the same } \\
\text { ward }\end{array}$ & 1.02 & $\begin{array}{l}0.96 \\
1.09\end{array}$ & 0.5 & 1.04 & $\begin{array}{l}0.98, \\
1.09\end{array}$ & 0.2 & 1.00 & $\begin{array}{l}0.90, \\
1.10\end{array}$ & $>0.9$ \\
\hline $\begin{array}{l}\text { Infectious } \\
\text { patients } \\
\text { with } \\
\text { hospital- } \\
\text { acquired } \\
\text { SARS-CoV- } \\
2 \text { on the } \\
\text { same ward }\end{array}$ & 1.45 & $\begin{array}{l}1.32, \\
1.58\end{array}$ & $<0.001$ & 1.61 & $\begin{array}{l}1.46 \\
1.76\end{array}$ & $<0.001$ & 1.44 & $\begin{array}{l}1.32, \\
1.57\end{array}$ & $<0.001$ \\
\hline $\begin{array}{l}\text { Infectious staff } \\
\text { on the same } \\
\text { ward }\end{array}$ & 1.66 & $\begin{array}{l}1.55, \\
1.78\end{array}$ & $<0.001$ & 1.83 & $\begin{array}{l}1.65, \\
2.02\end{array}$ & $<0.001$ & 1.56 & $\begin{array}{l}1.48, \\
1.64\end{array}$ & $<0.001$ \\
\hline \multicolumn{10}{|l|}{ Hospital } \\
\hline Hospital A & - & - & & - & - & & - & - & \\
\hline Hospital B & 1.54 & $\begin{array}{l}1.11 \\
2.13\end{array}$ & 0.01 & 1.66 & $\begin{array}{l}1.21 \\
2.28\end{array}$ & 0.002 & 1.55 & $\begin{array}{l}1.13, \\
2.13\end{array}$ & 0.007 \\
\hline Hospital C & 1.18 & $\begin{array}{l}0.92 \\
1.51\end{array}$ & 0.2 & 1.10 & $\begin{array}{l}0.86 \\
1.41\end{array}$ & 0.5 & 1.16 & $\begin{array}{l}0.91, \\
1.48\end{array}$ & 0.2 \\
\hline Hospital D & 1.34 & $\begin{array}{l}0.88 \\
2.00\end{array}$ & 0.2 & 1.42 & $\begin{array}{l}0.94, \\
2.10\end{array}$ & 0.08 & 1.22 & $\begin{array}{l}0.79 \\
1.83\end{array}$ & 0.4 \\
\hline
\end{tabular}


medRxiv preprint doi: https://doi.org/10.1101/2021.04.28.21256245; this version posted May 1, 2021. The copyright holder for this preprint (which was not certified by peer review) is the author/funder, who has granted medRxiv a license to display the preprint in perpetuity.

It is made available under a CC-BY-NC-ND 4.0 International license .

\begin{tabular}{|c|c|c|c|c|c|c|c|c|c|}
\hline $\begin{array}{l}\text { General } \\
\text { Ward }\end{array}$ & - & - & & - & - & & - & - & \\
\hline ICU/ HDU ${ }^{3}$ & 0.55 & $\begin{array}{l}0.39 \\
0.75\end{array}$ & $<0.001$ & 0.57 & $\begin{array}{l}0.41 \\
0.78\end{array}$ & 0.004 & 0.55 & $\begin{array}{l}0.39 \\
0.75\end{array}$ & $<0.001$ \\
\hline \multicolumn{10}{|l|}{ Phase $^{4}$} \\
\hline 1 & - & - & & - & - & & - & - & \\
\hline 2 & 1.60 & $\begin{array}{l}1.24 \\
2.05\end{array}$ & $<0.001$ & 1.67 & $\begin{array}{l}1.30 \\
2.16\end{array}$ & $<0.001$ & 1.25 & $\begin{array}{l}0.96, \\
1.61\end{array}$ & 0.09 \\
\hline 3 & 0.43 & $\begin{array}{l}0.34 \\
0.53\end{array}$ & $<0.001$ & 0.44 & $\begin{array}{l}0.36 \\
0.55\end{array}$ & $<0.001$ & 0.39 & $\begin{array}{l}0.32 \\
0.49\end{array}$ & $<0.001$ \\
\hline
\end{tabular}

${ }^{\mathrm{I}} \mathrm{OR}=$ Odds Ratio, $\mathrm{CI}=$ Confidence Interval

$417{ }^{2}$ Age measured in years.

$418{ }^{3}$ ICU/ HDU = Intensive care units/ High dependency units

$419{ }^{4}$ In addition to phases, calendar days was included as a non-linear independent variable in the logistic

420 regression, fitted with a linear spline function with two knots.

422 Table 4: Predictors of SARS-CoV-2 infection in healthcare workers from multivariable logistic

423 regression.

425 Using the alternative additive statistical model (figure 5), the strongest association was with 426 other infectious staff and patients with hospital-acquired SARSCoV-2. However, the additional

427 risks posed by exposures to these infectious $\mathrm{HCW}$ and patients to the susceptible HCW were less

428 compared to the that for susceptible patients. A single day of exposure to infected HCW and

429 patients with hospital-acquired SARS-CoV-2 patients on the same ward was associated with an

430 increased absolute daily risk of $0.10 \%$ (95\% CrI 0.04-0.20\%). The corresponding increase in

431 absolute daily risk from a day of exposure to an infected patient with community-acquired

432 SARS-CoV-2 was $0.05 \%(95 \%$ CrI 0.03-0.07\%).

434 The background transmission risks to HCW including that from community sources and

435 undetected cases amongst both $\mathrm{HCW}$ and patients were similar to those observed in the patients. 
medRxiv preprint doi: https://doi.org/10.1101/2021.04.28.21256245; this version posted May 1, 2021. The copyright holder for this preprint (which was not certified by peer review) is the author/funder, who has granted medRxiv a license to display the preprint in perpetuity.

It is made available under a CC-BY-NC-ND 4.0 International license .

436 The contribution of these undetected cases to the daily risk of SARS-CoV-2 acquisition was

437 about $0.03 \%(95 \mathrm{CrI} 0.02-0.03 \%)$ and $0.02 \%$ (95\% CrI $0.02-0.03 \%)$ for the susceptible patients

438 and HCW respectively. Findings from sensitivity analyses which excluded data from phase three

439 and using different prior distributions gave similar results as the main analyses (supplementary

440 material section 5)

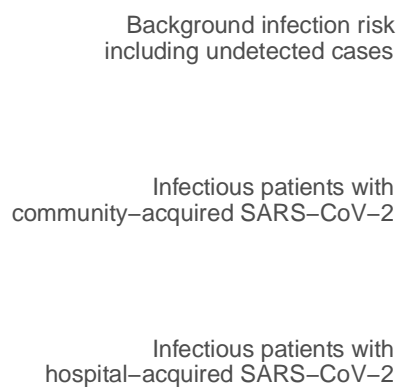

Infectious health care worker

443 Figure 5: Additional risk of suspected nosocomial acquisition of SARS-CoV-2 experienced by a

444 single susceptible healthcare worker contributed by i) infectious patients who acquired SARS-

445 CoV-2 in the community (second row); ii) infectious patients who acquired SARS-CoV-2 in the

446 hospital (third row) and iii) infectious healthcare workers (last row). A generalised mixed model

447 with an identity link was used, with assumed nosocomial acquisition (yes/no) on each day as the

448 dependent variable. Both the intercepts and slopes were allowed to vary by ward. The top row

449 shows the variation of the intercepts of the model, which represent the background infection risk 
medRxiv preprint doi: https://doi.org/10.1101/2021.04.28.21256245; this version posted May 1, 2021. The copyright holder for this preprint (which was not certified by peer review) is the author/funder, who has granted medRxiv a license to display the preprint in perpetuity.

It is made available under a CC-BY-NC-ND 4.0 International license .

450 posed by infectious patients and healthcare workers who are undetected. Each horizontal bar

451 represents the $95 \%$ credible interval of the estimate.

\section{Discussion}

454 The consistent finding in the above analysis is that the patients who acquired SARS-CoV-2 in

455 the hospital and, to a lesser degree, infectious healthcare workers likely working prior to the

456 onset of symptoms, were the most strongly associated with increased risk of SARS-CoV-2

457 transmission in the hospital setting. In contrast, exposure to patients who had acquired SARS-

$458 \mathrm{CoV}-2$ in the community appeared to be associated with, at most, modest increases in the daily

459 risk of infection for both healthcare staff and the other patients. We found evidence of a dose-

460 response effect: exposure to more infectious patients and healthcare staff were both associated

461 with increasing daily risk of acquiring SARS-CoV-2. These findings can parsimoniously be

462 explained by newly infected individuals having high transmission potential to patients and staff.

463 Multiple lines of evidence indicate that a substantial proportion of transmission precedes

464 symptom onset and point to rapidly declining infectiousness with time since symptom onset. [21,

465 26] Secondly, patients who acquired SARS-CoV-2 in the community are more likely to first

466 present with symptoms compatible with COVID-19 upon admission and be rapidly segregated

467 from the susceptible population with careful implementation of infection prevention and control 468 guidelines.

470 There are several limitations in our analysis. Firstly, the dates on which the infected patients first

471 developed symptoms were not available. Hence, we needed to assume that the PCR test swabs 
472 were taken on the symptom onset dates. While this assumption is reasonable based on the

473 analysis of a subset of data early in the pandemic, it is not true from phase three onwards when

474 weekly screening of patients regardless of symptoms was implemented. We addressed this by

475 performing sensitivity analysis comparing model outputs when using data collected during phase

476 one and two versus phase three (supplementary material section 5). Secondly, we assumed that

477 HCW were absent from work after the dates on which their first positive PCR test swabs were

478 taken or COVID-19 symptoms were first self-reported. However, where HCW experienced

479 minimal or no symptoms they may have continued to work. These issues could be further

480 explored using HCW absentee data in subsequent analysis.

482 A key challenge in this analysis is that the times of infection are unknown. This has led to the 483 adoption of various arbitrary cut-offs on length of stay prior to infection to define nosocomial 484 infection. Further analysis using data augmentation methods may potentially overcome this to 485 produce estimates that better account for different sources of uncertainty.

487 Other drivers of SARS-CoV-2 transmissions in the hospital setting not fully explained by

488 infection pressures, which we did not capture in the analysis, may include variation in ward 489 occupancy, community-acquired cases who did not develop symptoms until after hospitalisation, 490 change in nature or frequency of SARS-CoV-2 exposures throughout hospitalisation, or could 491 reflect frailties, i.e., those patients who have stayed 20 days and not been infected may be at 492 lower risk of infection. However, recent work using detailed epidemiological and genomic data 
medRxiv preprint doi: https://doi.org/10.1101/2021.04.28.21256245; this version posted May 1, 2021. The copyright holder for this preprint (which was not certified by peer review) is the author/funder, who has granted medRxiv a license to display the preprint in perpetuity.

It is made available under a CC-BY-NC-ND 4.0 International license .

493 to infer transmission networks echoed our main finding that patients are more likely to be

494 infected by other patients than by HCWs. [27]

495

496 Our findings support enhanced infection prevention and control efforts to prevent and identify

497 early hospital-onset SARS-CoV-2 infection. Where either community or local ward prevalence is

498 sufficiently high and resources permit, regular screening and prompt testing and identification of

499 such patients is important. Similarly, measures to ensure symptomatic staff are not at work,

500 including adequate sick pay arrangements, are vital. Regular staff screening is also likely to

501 reduce transmission. Staff acquisition and transient asymptomatic carriage, contamination of

502 equipment and the general environment or the air are possible mediators of transmission events

503 assigned in the analysis as patient-to-patient and need further investigation. The relatively low

504 risk of transmission associated with patients with suspected community-acquired COVID-19

505 suggests that for these patients the peak of their infectivity may have passed such that existing

506 infection prevention and control policies including universal PPE, prompt testing and isolation of

507 suspected or known cases [16] are sufficient to mitigate most of the remaining infectiousness.

508 Our analysis shows that despite these measures patients and staff are at risk from newly infected

509 individuals. Due to the difficulties in disentangling the effect of infection prevention and control

510 measures and surges in SARS-CoV-2 in the community setting, we cannot provide conclusive

511 evidence on how interventions around hospital-onset cases could be enhanced. However, others

512 have suggested enhanced PPE for HCW and ventilation may play a role. [28-31] 
medRxiv preprint doi: https://doi.org/10.1101/2021.04.28.21256245; this version posted May 1, 2021. The copyright holder for this preprint (which was not certified by peer review) is the author/funder, who has granted medRxiv a license to display the preprint in perpetuity.

It is made available under a CC-BY-NC-ND 4.0 International license .

514 In conclusion, our data provide strong evidence that newly infected patients pose a high risk of

515 onward transmission to patients and healthcare workers in hospital. Further investigation is

516 needed into how best to enhance infection control and prevention efforts around these patients.

\section{Authors' contributions}

519 DWE and BSC conceptualized this work. MY, DWE and BSC performed the statistical analysis.

520 MY drafted the first version of the manuscript. DWE, MY and KJ verified the underlying data.

521 All authors reviewed and edited subsequent versions of the manuscript.

\section{Sources of funding}

524 MY is supported by the Singapore National Medical Research Council Research Fellowship

525 (Grant ref: NMRC/Fellowship/0051/2017). BSC acknowledges support from the Medical

526 Research Council (Grant Ref: MR/V028456/1). TMW is a Wellcome Trust Clinical Career

527 Development Fellow (214560/Z/18/Z). This work was also supported by the National Institute

528 for Health Research Health Protection Research Unit (NIHR HPRU) in Healthcare Associated

529 Infections and Antimicrobial Resistance at Oxford University in partnership with Public Health

530 England (PHE) (NIHR200915), the NIHR Biomedical Research Centre, Oxford, and the NIHR

531 HPRU in Emerging and Zoonotic Infections at University of Liverpool in partnership with PHE,

532 in collaboration with Liverpool School of Tropical Medicine and the University of Oxford

533 (NIHR200907).

534

535 Conflicts of interest 
medRxiv preprint doi: https://doi.org/10.1101/2021.04.28.21256245; this version posted May 1, 2021. The copyright holder for this preprint (which was not certified by peer review) is the author/funder, who has granted medRxiv a license to display the preprint in perpetuity.

It is made available under a CC-BY-NC-ND 4.0 International license .

536 DWE declares personal fees from Gilead outside the submitted work.

\section{Data sharing}

539 The datasets analysed during the current study are not publicly available as they contain personal

540 data but are available from the Infections in Oxfordshire Research Database

541 (https://oxfordbrc.nihr.ac.uk/research-themes-overview/antimicrobial-resistance-and-

542 modernising-microbiology/infections-in-oxfordshire-research-database-iord/), subject to an

543 application and research proposal meeting the ethical and governance requirements of the

544 Database. All analysis codes are available at

545 https://github.com/moyinNUHS/covid HospTransmissionDynamics.

\section{Acknowledgement}

548 The authors acknowledge valuable contributions from Omar Risk, Hannah Chase, Ishta Sharma,

549 Sarah Peters, Tamsin Cargill, Grace Barnes, Josh Hamblin, Jenny Tempest-Mitchell, Archie

550 Lodge, Sai Parepalli, Raghav Sudarshan, Hannah Callaghan, Imogen Vorley, Ashley Elder,

551 Danica Fernandes, Gurleen Kaur, Bara'a Elhag, Edward David, Rumbi Mutenga, Dylan Riley,

552 Emel Yildirim, and Naomi Hudson from Oxford University Hospitals NHS Foundation Trust

553 and University of Oxford Medical School for data collection. 
medRxiv preprint doi: https://doi.org/10.1101/2021.04.28.21256245; this version posted May 1, 2021. The copyright holder for this preprint (which was not certified by peer review) is the author/funder, who has granted medRxiv a license to display the preprint in perpetuity. It is made available under a CC-BY-NC-ND 4.0 International license .

\section{References}

557 1. Rickman HM, Rampling T, Shaw K, Martinez-Garcia G, Hail L, Coen P, Shahmanesh M, 558 Shin GY, Nastouli E, Houlihan CF. Nosocomial Transmission of Coronavirus Disease 2019:

559 A Retrospective Study of 66 Hospital-acquired Cases in a London Teaching Hospital. Clin Infect Dis. 2021 Feb 16;72(4):690-693. doi: 10.1093/cid/ciaa816. PMID: 32562422; PMCID: PMC7337682.

2. Wang X, Zhou Q, He Y, Liu L, Ma X, Wei X, Jiang N, Liang L, Zheng Y, Ma L, Xu Y, Yang D, Zhang J, Yang B, Jiang N, Deng T, Zhai B, Gao Y, Liu W, Bai X, Pan T, Wang G, Chang Y, Zhang Z, Shi H, Ma WL, Gao Z. Nosocomial outbreak of COVID-19 pneumonia in Wuhan, China. Eur Respir J. 2020 Jun 4;55(6):2000544. doi: 10.1183/13993003.00544-

3. Zhou F, Yu T, Du R, Fan G, Liu Y, Liu Z, Xiang J, Wang Y, Song B, Gu X, Guan L, Wei Y, mortality of adult inpatients with COVID-19 in Wuhan, China: a retrospective cohort study. Lancet. 2020 Mar 28;395(10229):1054-1062. doi: 10.1016/S0140-6736(20)30566-3. Epub 2020 Mar 11. Erratum in: Lancet. 2020 Mar 28;395(10229):1038. Erratum in: Lancet. 2020

573 4. Zhou Q, Gao Y, Wang X, Liu R, Du P, Wang X, Zhang X, Lu S, Wang Z, Shi Q, Li W, Ma Y, Luo X, Fukuoka T, Ahn HS, Lee MS, Liu E, Chen Y, Luo Z, Yang K; COVID-19 Evidence and Recommendations Working Group. Nosocomial infections among patients with COVID-19, SARS and MERS: a rapid review and meta-analysis. Ann Transl Med. 
medRxiv preprint doi: https://doi.org/10.1101/2021.04.28.21256245; this version posted May 1, 2021. The copyright holder for this preprint (which was not certified by peer review) is the author/funder, who has granted medRxiv a license to display the preprint in perpetuity. It is made available under a CC-BY-NC-ND 4.0 International license .

2020 May;8(10):629. doi: 10.21037/atm-20-3324. PMID: 32566566; PMCID: PMC7290630.

5. Lessells R, Moosa Y, de Oliveira T. Report into a nosocomial outbreak of coronavirus disease 2019 (COVID $\square$ 19) at Netcare St. Augustine’s Hospital. KwaZulu $\square$ Natal Research Innovation and Sequencing Platform (KRISP). https://www.krisp.org.za/news.php?id=421(pdf) 2020

6. Arons MM, Hatfield KM, Reddy SC, Kimball A, James A, Jacobs JR, Taylor J, Spicer K, Bardossy AC, Oakley LP, Tanwar S, Dyal JW, Harney J, Chisty Z, Bell JM, Methner M, Paul P, Carlson CM, McLaughlin HP, Thornburg N, Tong S, Tamin A, Tao Y, Uehara A, Harcourt J, Clark S, Brostrom-Smith C, Page LC, Kay M, Lewis J, Montgomery P, Stone ND, Clark TA, Honein MA, Duchin JS, Jernigan JA; Public Health-Seattle and King and Transmission in a Skilled Nursing Facility. N Engl J Med. 2020 May 28;382(22):2081-

7. Iacobucci G. Covid-19: Doctors sound alarm over hospital transmissions. BMJ. 2020 May

594 8. Rhee C, Baker M, Vaidya V, Tucker R, Resnick A, Morris CA, Klompas M; CDC Prevention Epicenters Program. Incidence of Nosocomial COVID-19 in Patients 1;3(9):e2020498. doi: 10.1001/jamanetworkopen.2020.20498. PMID: 32902653; PMCID: PMC7489854. 
medRxiv preprint doi: https://doi.org/10.1101/2021.04.28.21256245; this version posted May 1, 2021. The copyright holder for this preprint (which was not certified by peer review) is the author/funder, who has granted medRxiv a license to display the preprint in perpetuity. It is made available under a CC-BY-NC-ND 4.0 International license .

9. Carter B, Collins JT, Barlow-Pay F, Rickard F, Bruce E, Verduri A, Quinn TJ, Mitchell E, Price A, Vilches-Moraga A, Stechman MJ, Short R, Einarsson A, Braude P, Moug S, Myint

10. Bhattacharya A, Collin SM, Stimson J, Thelwall S, Nsonwu O, Gerver S, Robotham J, Wilcox M, Hopkins S, Hope R. Healthcare-associated COVID-19 in England: a national data linkage study. medRxiv 2021 Feb;21251625; doi:

11. Nguyen LH, Drew DA, Joshi AD, Guo CG, Ma W, Mehta RS, Sikavi DR, Lo CH, Kwon S, Song M, Mucci LA, Stampfer MJ, Willett WC, Eliassen AH, Hart JE, Chavarro JE, RichEdwards JW, Davies R, Capdevila J, Lee KA, Lochlainn MN, Varsavsky T, Graham MS, Sudre CH, Cardoso MJ, Wolf J, Ourselin S, Steves CJ, Spector TD, Chan AT. Risk of COVID-19 among frontline healthcare workers and the general community: a prospective N, Boreham I, Thomas H, Lewis J, Bell I, Bell JI, Newton JN, Farrar J, Diamond I, Benton 
medRxiv preprint doi: https://doi.org/10.1101/2021.04.28.21256245; this version posted May 1, 2021. The copyright holder for this preprint (which was not certified by peer review) is the author/funder, who has granted medRxiv a license to display the preprint in perpetuity. It is made available under a CC-BY-NC-ND 4.0 International license .

Survey. Lancet Public Health. 2021 Jan;6(1):e30-e38. doi: 10.1016/S2468-2667(20)30282-6.

Epub 2020 Dec 11. PMID: 33308423; PMCID: PMC7786000.

623 13. Pollán M, Pérez-Gómez B, Pastor-Barriuso R, Oteo J, Hernán MA, Pérez-Olmeda M,

624 Sanmartín JL, Fernández-García A, Cruz I, Fernández de Larrea N, Molina M, Rodríguez-

625 Cabrera F, Martín M, Merino-Amador P, León Paniagua J, Muñoz-Montalvo JF, Blanco F,

626 Yotti R; ENE-COVID Study Group. Prevalence of SARS-CoV-2 in Spain (ENE-COVID): a

627 nationwide, population-based seroepidemiological study. Lancet. 2020 Aug 22;396(10250):535-544. doi: 10.1016/S0140-6736(20)31483-5. Epub 2020 Jul 6. PMID: 32645347; PMCID: PMC7336131.

14. Quigley AL, Stone H, Nguyen PY, Chughtai AA, MacIntyre CR. Estimating the burden of

631 COVID-19 on the Australian healthcare workers and health system during the first six months of the pandemic. Int J Nurs Stud. 2021 Feb;114:103811. doi: 10.1016/j.ijnurstu.2020.103811. Epub 2020 Oct 29. PMID: 33352440; PMCID: PMC7598370.

635 15. Oliver D. David Oliver: Could we do better on hospital acquired covid-19 in a future wave? BMJ. 2021 Jan 13;372:n70. doi: 10.1136/bmj.n70. PMID: 33441317.

637 16. Evans S, Agnew E, Vynnycky E, Robotham J. The impact of testing and infection

638 prevention and control strategies on within-hospital transmission dynamics of COVID-19 in 639 English hospitals. medRxiv. 2020 May;20095562. doi:

$640 \quad$ https://doi.org/10.1101/2020.05.12.20095562

641 17. Eyre DW, Lumley SF, O'Donnell D, Campbell M, Sims E, Lawson E, Warren F, James T, 642 Cox S, Howarth A, Doherty G, Hatch SB, Kavanagh J, Chau KK, Fowler PW, Swann J, 
medRxiv preprint doi: https://doi.org/10.1101/2021.04.28.21256245; this version posted May 1, 2021. The copyright holder for this preprint (which was not certified by peer review) is the author/funder, who has granted medRxiv a license to display the preprint in perpetuity. It is made available under a CC-BY-NC-ND 4.0 International license .

18. Lumley SF, O'Donnell D, Stoesser NE, Matthews PC, Howarth A, Hatch SB, Marsden BD, Incidence of SARS-CoV-2 Infection in Health Care Workers. N Engl J Med. 2021 Feb

19. Lauer SA, Grantz KH, Bi Q, Jones FK, Zheng Q, Meredith HR, Azman AS, Reich NG,

660 Lessler J. The Incubation Period of Coronavirus Disease 2019 (COVID-19) From Publicly

661 Reported Confirmed Cases: Estimation and Application. Ann Intern Med. 2020 May 
medRxiv preprint doi: https://doi.org/10.1101/2021.04.28.21256245; this version posted May 1, 2021. The copyright holder for this preprint (which was not certified by peer review) is the author/funder, who has granted medRxiv a license to display the preprint in perpetuity. It is made available under a CC-BY-NC-ND 4.0 International license .

664 20. European Centre for Disease Prevention and Control. Surveillance definitions for COVID-

665 19. $2020 \mathrm{Jul}$. URL https://www.ecdc. europa.eu/en/covid-19/surveillance/surveillance-

666 definitions.

667 21. Ferretti L, Wymant C, Kendall M, Zhao L, Nurtay A, Abeler-Dörner L, Parker M, Bonsall

668 D, Fraser C. Quantifying SARS-CoV-2 transmission suggests epidemic control with digital

669 contact tracing. Science. 2020 May 8;368(6491):eabb6936. doi: 10.1126/science.abb6936.

670 Epub 2020 Mar 31. PMID: 32234805; PMCID: PMC7164555.

671 22. Wood SN. Generalized Additive Models: An Introduction with R. Chapman and Hall/CRC,

$672 \quad$ 2nd edition, 2017.

673 23. Plummer M. JAGS: A program for analysis of Bayesian graphical models using Gibbs

674 sampling. Third international workshop on Distributed Statistical Computing. 2003 Mar.

675 URL: https://www.r-project.org/conferences/DSC-2003/Proceedings/Plummer.pdf

676 24. Watanabe S, Opper M. Asymptotic equivalence of bayes cross validation and widely

677 applicable information criterion in singular learning theory. Journal of machine learning

$678 \quad$ research. 2010; 11(3571-3594).

679 25. R Core Team. R: A Language and Environment for Statistical Computing. R Foundation for

680 Statistical Computing, Vienna, Austria, 2017. URL https://www.R-project.org/.

681 26. He X, Lau EHY, Wu P, Deng X, Wang J, Hao X, Lau YC, Wong JY, Guan Y, Tan X, Mo

682 X, Chen Y, Liao B, Chen W, Hu F, Zhang Q, Zhong M, Wu Y, Zhao L, Zhang F, Cowling

683 BJ, Li F, Leung GM. Temporal dynamics in viral shedding and transmissibility of COVID-

684 19. Nat Med. 2020 May;26(5):672-675. doi: 10.1038/s41591-020-0869-5. Epub 2020 Apr

685 15. Erratum in: Nat Med. 2020 Sep;26(9):1491-1493. PMID: 32296168. 
medRxiv preprint doi: https://doi.org/10.1101/2021.04.28.21256245; this version posted May 1, 2021. The copyright holder for this preprint (which was not certified by peer review) is the author/funder, who has granted medRxiv a license to display the preprint in perpetuity. It is made available under a CC-BY-NC-ND 4.0 International license .

686

687

688

689

690

691

692

693

694

695

696

697

698

699

700

701

702

703

704

27. Illingworth C, Hamilton W, Warne B, Routledge M, Popay A, Jackson C, Fieldman T, Meredith L W, Houldcroft C J, Hosmillo M, and et al. Superspreaders drive the largest outbreaks of hospital onset COVID-19 infection. 2021 Feb. URL osf.io/wmkn3.

28. Liu M, Cheng SZ, Xu KW, Yang Y, Zhu QT, Zhang H, Yang DY, Cheng SY, Xiao H, Wang JW, Yao HR, Cong YT, Zhou YQ, Peng S, Kuang M, Hou FF, Cheng KK, Xiao HP. Use of personal protective equipment against coronavirus disease 2019 by healthcare professionals in Wuhan, China: cross sectional study. BMJ. 2020 Jun 10;369:m2195. doi: 10.1136/bmj.m2195. PMID: 32522737; PMCID: PMC7284314.

29. Nissen K, Krambrich J, Akaberi D, Hoffman T, Ling J, Lundkvist Å, Svensson L, Salaneck E. Long-distance airborne dispersal of SARS-CoV-2 in COVID-19 wards. Sci Rep. 2020 Nov 11;10(1):19589. doi: 10.1038/s41598-020-76442-2. PMID: 33177563; PMCID: PMC7659316.

30. Birgand G, Peiffer-Smadja N, Fournier S, Kerneis S, Lescure FX, Lucet JC. Assessment of Air Contamination by SARS-CoV-2 in Hospital Settings. JAMA Netw Open. 2020 Dec 1;3(12):e2033232. doi: 10.1001/jamanetworkopen.2020.33232. Erratum in: JAMA Netw Open. 2021 Jan 4;4(1):e2037904. PMID: 33355679; PMCID: PMC7758808.

31. Richterman A, Meyerowitz EA, Cevik M. Hospital-Acquired SARS-CoV-2 Infection: Lessons for Public Health. JAMA. 2020 Nov 13. doi: 10.1001/jama.2020.21399. Epub ahead of print. PMID: 33185657. 
medRxiv preprint doi: https://doi.org/10.1101/2021.04.28.21256245; this version posted May 1, 2021. The copyright holder for this preprint (which was not certified by peer review) is the author/funder, who has granted medRxiv a license to display the preprint in perpetuity.

It is made available under a CC-BY-NC-ND 4.0 International license .

\section{Supplementary material}

706

707

708

709

710

711

712

713

714

715

716

717 positive tests), and patients who acquired SARS-CoV-2 in the hospital (i.e., inpatient on the sixth

718 day prior to first positive tests) respectively. For these plots, patients were considered to be

719 infectious for a period of ten days, starting one day after the day of the presumed infection event.

720 [20] The last row shows the number of infectious healthcare workers. Healthcare workers were 721 considered infectious from the day of the infection event until a day before their first positive 722 PCR test or report of COVID-19 related symptoms, whichever was earlier.

1. The timelines of potential nosocomial transmission events and the numbers of infectious patients and $\mathrm{HCW}$.

Figure S1. Weekly average numbers of transmission events and infectious patients and healthcare workers in wards with at least 30 members of staff tested and 20 available patient beds. The top row for each panel of graphs shows the weekly average number of patients who had a positive SARS-CoV-2 PCR test and who were defined to have been infected in the hospital on that ward during the indicated week based on the assumed incubation period of five days. The second and third rows for each panel show the numbers of infectious patients defined as having community-acquired SARS-CoV-2 infections (i.e., no hospitalisation in the 20 days prior to first 
medRxiv preprint doi: https://doi.org/10.1101/2021.04.28.21256245; this version posted May 1, 2021. The copyright holder for this preprint (which was not certified by peer review) is the author/funder, who has granted medRxiv a license to display the preprint in perpetuity. It is made available under a CC-BY-NC-ND 4.0 International license.
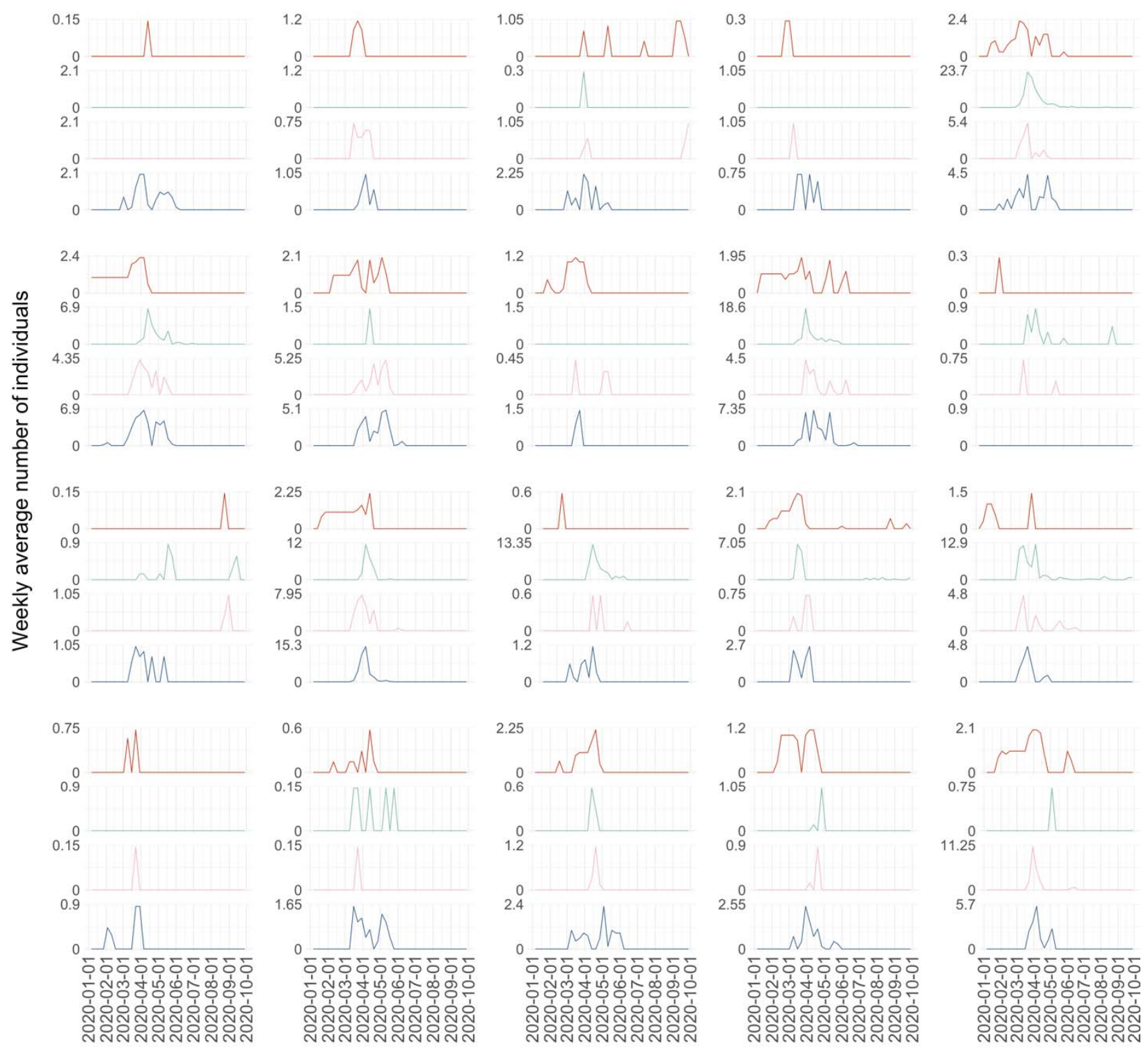

- Patients with new nosocomial infections

Patients with community-acquired SARS-CoV-2 on the same ward who are infectious

Patients with hospital-acquired SARS-CoV-2 on the same ward who are infectious who are infectious 
medRxiv preprint doi: https://doi.org/10.1101/2021.04.28.21256245; this version posted May 1, 2021. The copyright holder for this preprint (which was not certified by peer review) is the author/funder, who has granted medRxiv a license to display the preprint in perpetuity.

It is made available under a CC-BY-NC-ND 4.0 International license .

\section{$731 \quad$ 2. Logistic regression (Model 1) results}

\section{$732 \quad 2.1$ Univariable analysis (Model $\mathbf{1}_{\text {univariable }}$ )}

733 Table S1: Univariable logistic regression results where the outcome is patient SARS-CoV-2

734 infection during the hospital stay (model $\left.P 1_{\text {univariable }}\right)$.

\begin{tabular}{|c|c|c|c|c|c|c|c|c|c|c|c|c|}
\hline \multirow[b]{3}{*}{ Characteristics } & \multicolumn{12}{|c|}{ Incubation period } \\
\hline & \multicolumn{4}{|c|}{5 days } & & \multicolumn{3}{|c|}{3 days } & \multicolumn{4}{|c|}{7 days } \\
\hline & $\mathbf{N}$ & $\begin{array}{c}\text { OR } \\
1\end{array}$ & $\begin{array}{c}95 \% \\
\text { CI }^{1}\end{array}$ & $\begin{array}{c}\text { p- } \\
\text { value }\end{array}$ & $\mathbf{N}$ & $\mathbf{O R}^{1}$ & $\begin{array}{c}95 \% \\
\text { CI }^{1}\end{array}$ & $\begin{array}{c}\text { p- } \\
\text { value }\end{array}$ & $\mathbf{N}$ & $\mathbf{O R}^{1}$ & $\begin{array}{c}95 \% \\
\mathrm{CI}^{1}\end{array}$ & $\begin{array}{c}\text { p- } \\
\text { value }\end{array}$ \\
\hline Age & 148,998 & $\begin{array}{c}1.0 \\
4\end{array}$ & $\begin{array}{l}1.03, \\
1.05\end{array}$ & $\begin{array}{c}<0.00 \\
1\end{array}$ & 192,293 & 1.03 & $\begin{array}{l}1.02, \\
1.04\end{array}$ & $\begin{array}{c}<0.00 \\
1\end{array}$ & 121,299 & 1.04 & $\begin{array}{l}1.03 \\
1.06\end{array}$ & $\begin{array}{c}<0.00 \\
1\end{array}$ \\
\hline Sex & 148,998 & & & & 192,293 & & & & 121,299 & & & \\
\hline Female & & - & - & & & - & - & & & - & - & \\
\hline Male & & $\begin{array}{c}1.0 \\
4\end{array}$ & $\begin{array}{c}0.75 \\
1.44\end{array}$ & 0.8 & & 0.97 & $\begin{array}{c}0.69 \\
1.35\end{array}$ & 0.8 & & 0.88 & $\begin{array}{c}0.62 \\
1.25\end{array}$ & 0.5 \\
\hline Ethnic group & 119,511 & & & & 154,446 & & & & 97,130 & & & \\
\hline White & & - & - & & & - & - & & & - & - & \\
\hline Non-white & & $\begin{array}{c}0.1 \\
7\end{array}$ & $\begin{array}{l}0.03 \\
0.53\end{array}$ & 0.013 & & 0.00 & $\begin{array}{l}0.00 \\
0.21\end{array}$ & 0.93 & & 0.18 & $\begin{array}{l}0.03 \\
0.57\end{array}$ & 0.017 \\
\hline $\begin{array}{l}\text { Infectious } \\
\text { patients with } \\
\text { community- } \\
\text { acquired SARS- } \\
\text { CoV-2 on the } \\
\text { same ward }\end{array}$ & 150,884 & $\begin{array}{c}1.4 \\
6\end{array}$ & $\begin{array}{l}1.34 \\
1.57\end{array}$ & $\begin{array}{c}<0.00 \\
1\end{array}$ & 194,205 & 1.36 & $\begin{array}{l}1.25 \\
1.47\end{array}$ & $\begin{array}{c}<0.00 \\
1\end{array}$ & 123,159 & 1.55 & $\begin{array}{l}1.38 \\
1.69\end{array}$ & $\begin{array}{c}<0.00 \\
1\end{array}$ \\
\hline $\begin{array}{l}\text { Infectious } \\
\text { patients with } \\
\text { hospital-acquired } \\
\text { SARS-CoV-2 on } \\
\text { the same ward }\end{array}$ & 150,884 & $\begin{array}{c}2.7 \\
7\end{array}$ & $\begin{array}{l}2.52 \\
3.02\end{array}$ & $\begin{array}{c}<0.00 \\
1\end{array}$ & 194,205 & 3.13 & $\begin{array}{l}2.83 \\
3.44\end{array}$ & $\begin{array}{c}<0.00 \\
1\end{array}$ & 123,159 & 2.60 & $\begin{array}{l}2.35 \\
2.87\end{array}$ & $\begin{array}{c}<0.00 \\
1\end{array}$ \\
\hline $\begin{array}{l}\text { Infectious } \\
\text { healthcare } \\
\text { worker on the } \\
\text { same ward }\end{array}$ & 142,644 & $\begin{array}{c}2.2 \\
7\end{array}$ & $\begin{array}{l}2.06 \\
2.48\end{array}$ & $\begin{array}{c}<0.00 \\
1\end{array}$ & 182,772 & 3.03 & $\begin{array}{l}2.64, \\
3.44\end{array}$ & $\begin{array}{c}<0.00 \\
1\end{array}$ & 116,750 & 1.98 & $\begin{array}{l}1.83 \\
2.13\end{array}$ & $\begin{array}{c}<0.00 \\
1\end{array}$ \\
\hline Hospital & 150,884 & & & & 194,205 & & & & 123,159 & & & \\
\hline Hospital A & & - & - & & & - & - & & & - & - & \\
\hline Hospital B & & $\begin{array}{c}4.4 \\
1\end{array}$ & $\begin{array}{l}2.72 \\
9.92\end{array}$ & $\begin{array}{c}<0.00 \\
1\end{array}$ & & 4.51 & $\begin{array}{l}2.12 \\
10.70\end{array}$ & $\begin{array}{c}<0.00 \\
1\end{array}$ & & 5.82 & $\begin{array}{l}2.71, \\
14.40\end{array}$ & $\begin{array}{c}<0.00 \\
1\end{array}$ \\
\hline Hospital C & & $\begin{array}{c}2.1 \\
0\end{array}$ & $\begin{array}{l}1.17 \\
4.71\end{array}$ & 0.024 & & 2.53 & $\begin{array}{l}1.31 \\
5.66\end{array}$ & 0.012 & & 2.38 & $\begin{array}{l}1.18 \\
5.69\end{array}$ & 0.028 \\
\hline Hospital D & & $\begin{array}{c}4.2 \\
3\end{array}$ & $\begin{array}{l}2.00 \\
9.74\end{array}$ & $\begin{array}{c}<0.00 \\
1\end{array}$ & & 4.76 & $\begin{array}{l}2.15 \\
11.5\end{array}$ & $\begin{array}{c}<0.00 \\
1\end{array}$ & & 4.14 & $\begin{array}{c}1.78 \\
10.70\end{array}$ & $\begin{array}{c}<0.00 \\
2\end{array}$ \\
\hline Type of ward & 150,884 & & & & 194,205 & & & & $\begin{array}{c}123,159 \\
5\end{array}$ & & & \\
\hline General Ward & & - & - & & & - & - & & & - & - & \\
\hline ICU/ HDU ${ }^{2}$ & & $\begin{array}{c}0.4 \\
9\end{array}$ & $\begin{array}{c}0.19 \\
1.01\end{array}$ & 0.087 & & 0.37 & $\begin{array}{l}0.11 \\
0.87\end{array}$ & 0.05 & & 0.17 & $\begin{array}{l}0.03 \\
0.54\end{array}$ & 0.014 \\
\hline Phase & 150,884 & & & & 194,205 & & & & 123,159 & & & \\
\hline $\mathbf{1}$ & & - & - & & & - & - & & & - & - & \\
\hline 2 & & $\begin{array}{c}3.0 \\
0\end{array}$ & $\begin{array}{l}2.01 \\
4.40\end{array}$ & $\begin{array}{c}<0.00 \\
1\end{array}$ & & 4.24 & $\begin{array}{l}2.85 \\
6.27\end{array}$ & $\begin{array}{c}<0.00 \\
1\end{array}$ & & 2.50 & $\begin{array}{l}1.62 \\
3.76\end{array}$ & $\begin{array}{c}<0.00 \\
1\end{array}$ \\
\hline
\end{tabular}


medRxiv preprint doi: https://doi.org/10.1101/2021.04.28.21256245; this version posted May 1, 2021. The copyright holder for this preprint (which was not certified by peer review) is the author/funder, who has granted medRxiv a license to display the preprint in perpetuity. It is made available under a CC-BY-NC-ND 4.0 International license.

\begin{tabular}{lcccccccccccc}
\hline 3 & & 0.2 & 0.16, & $<0.00$ & & 0.32 & 0.21, & $<0.00$ & & 0.18 & 0.11, & $<0.00$ \\
& & 4 & 0.35 & 1 & & & 0.48 & 1 & & 0.28 & 1 \\
\hline Calendar day & 150,884 & 1.0 & 1.00, & 0.017 & 194,205 & 1.02 & 1.00, & 0.022 & 123,159 & 1.00 & 0.98, & 0.8 \\
& & 2 & 1.04 & & & & 1.04 & & & 1.02 & \\
\hline Day of stay & 150,884 & 0.9 & 0.98, & 0.008 & 194,205 & 0.99 & 0.98, & 0.039 & 123,159 & 0.98 & 0.97, & 0.001 \\
& & 9 & 1.00 & & & & 1.00 & & & & 0.99 &
\end{tabular}

${ }^{1} \mathrm{OR}=$ Odds Ratio, $\mathrm{CI}=$ Confidence Interval

${ }^{2}$ ICU/ HDU = Intensive care units/ High dependency units 
medRxiv preprint doi: https://doi.org/10.1101/2021.04.28.21256245; this version posted May 1, 2021. The copyright holder for this preprint (which was not certified by peer review) is the author/funder, who has granted medRxiv a license to display the preprint in perpetuity.

It is made available under a CC-BY-NC-ND 4.0 International license .

737 Table S2: Univariable logistic regression results where the outcome is healthcare worker

738 COVID-19 infection during the hospital stay (model $H 1_{\text {univariate }}$ ).

\begin{tabular}{|c|c|c|c|c|c|c|c|c|c|c|c|c|}
\hline \multirow{3}{*}{$\begin{array}{l}\text { Characteristi } \\
\text { cs }\end{array}$} & \multicolumn{12}{|c|}{ Incubation period } \\
\hline & \multicolumn{5}{|c|}{5 days } & \multicolumn{3}{|c|}{3 days } & \multicolumn{4}{|c|}{7 days } \\
\hline & $\mathbf{N}$ & OR $^{1}$ & $95 \% \mathrm{CI}^{1}$ & p-value & $\mathbf{N}$ & $\mathrm{OR}^{1}$ & $95 \% \mathrm{CI}^{1}$ & p-value & $\mathbf{N}$ & $\mathrm{OR}^{1}$ & $95 \% \mathrm{CI}^{1}$ & p-value \\
\hline$\overline{\text { Age }}$ & $1,350,592$ & 1.00 & $0.99,1.01$ & 0.9 & $1,361,784$ & 1.00 & $0.99,1.01$ & 0.9 & $1,339,400$ & 1.00 & $0.99,1.01$ & 0.9 \\
\hline Sex & $1,350,592$ & & & & $1,361,784$ & & & & $1,339,400$ & & & \\
\hline Female & & - & - & & & - & - & & & - & - & \\
\hline Male & & 0.97 & $0.80,1.18$ & 0.8 & & 0.97 & $0.80,1.18$ & 0.8 & & 0.97 & $0.80,1.18$ & 0.8 \\
\hline Role & $1,350,592$ & & & & $1,361,784$ & & & & $1,339,400$ & & & \\
\hline Doctor & & - & - & & & - & - & & & - & - & \\
\hline Nurse & & 1.47 & $1.18,1.86$ & & $<0.001$ & 1.47 & $1.18,1.86$ & $<0.001$ & & 1.47 & $1.18,1.86$ & $<0.001$ \\
\hline $\begin{array}{l}\text { Allied } \\
\text { Health }\end{array}$ & & 1.03 & $0.80,1.34$ & 0.8 & & 1.03 & $0.80,1.34$ & 0.8 & & 1.03 & $0.80,1.34$ & 0.8 \\
\hline $\begin{array}{l}\text { Non-clinical } \\
\text { staff }\end{array}$ & & 0.95 & $0.70,1.28$ & 0.7 & & 0.95 & $0.70,1.28$ & 0.7 & & 0.95 & $0.70,1.28$ & 0.7 \\
\hline $\begin{array}{l}\text { Infectious } \\
\text { patients with } \\
\text { community- } \\
\text { acquired } \\
\text { SARS-CoV } 2 \\
\text { on the same } \\
\text { ward }\end{array}$ & $1,074,079$ & 1.30 & $1.25,1.35$ & $<0.001$ & $1,074,079$ & 1.25 & $1.21,1.28$ & $<0.001$ & $1,055,216$ & 1.38 & $1.27,1.49$ & $<0.001$ \\
\hline $\begin{array}{l}\text { Infectious } \\
\text { patients with } \\
\text { hospital- } \\
\text { acquired } \\
\text { SARS-CoV-2 } \\
\text { on the same } \\
\text { ward }\end{array}$ & $1,063,844$ & 2.23 & $2.08,2.36$ & $<0.001$ & $1,074,079$ & 2.40 & $2.25,2.55$ & $<0.001$ & $1,055,216$ & 2.17 & $2.04,2.30$ & $<0.001$ \\
\hline $\begin{array}{l}\text { Infectious } \\
\text { healthcare } \\
\text { worker on the } \\
\text { same ward }\end{array}$ & $1,350,592$ & 1.96 & $1.87,2.05$ & $<0.001$ & $1,361,784$ & 2.36 & $2.21,2.52$ & $<0.001$ & $1,374,267$ & 1.77 & $1.71,1.84$ & $<0.001$ \\
\hline Hospital & $1,350,592$ & & & & $1,361,784$ & & & & $1,339,400$ & & & \\
\hline Hospital A & & - & - & & & - & - & & & - & - & \\
\hline Hospital B & & 1.95 & $1.46,2.59$ & $<0.001$ & & 1.95 & $1.46,2.59$ & $<0.001$ & & 1.95 & $1.46,2.59$ & $<0.001$ \\
\hline Hospital C & & 1.15 & $0.93,1.45$ & 0.2 & & 1.15 & $0.93,1.45$ & 0.2 & & 1.15 & $0.93,1.45$ & 0.2 \\
\hline Hospital D & & 1.68 & $1.18,2.37$ & 0.003 & & 1.68 & $1.18,2.37$ & 0.003 & & 1.68 & $1.18,2.37$ & 0.003 \\
\hline Type of ward & $1,350,592$ & & & & $1,361,784$ & & & & $1,339,400$ & & & \\
\hline $\begin{array}{l}\text { General } \\
\text { Ward }\end{array}$ & & - & - & & & - & - & & & - & - & \\
\hline${\mathrm{ICU} / \mathrm{HDU}^{2}}^{2}$ & & 0.61 & $0.44,0.81$ & 0.001 & & 0.61 & $0.44,0.81$ & 0.001 & & 0.61 & $0.44,0.81$ & 0.001 \\
\hline Phase & $1,350,592$ & & & & $1,361,784$ & & & & $1,339,400$ & & & \\
\hline 1 & & - & - & & & - & - & & & - & - & \\
\hline 2 & & 2.59 & $2.14,3.13$ & $<0.001$ & & 1.91 & $1.57,2.32$ & $<0.001$ & & 1.91 & $1.57,2.32$ & $<0.001$ \\
\hline 3 & & 0.40 & $0.33,0.48$ & $<0.001$ & & 0.33 & $0.27,0.39$ & $<0.001$ & & 0.34 & $0.28,0.41$ & $<0.001$ \\
\hline Calendar day & $1,350,592$ & 0.99 & $0.98,1.00$ & 0.012 & $1,361,784$ & 0.98 & $0.97,0.99$ & $<0.001$ & $1,339,400$ & 1.00 & $0.99,1.01$ & 0.8 \\
\hline
\end{tabular}


medRxiv preprint doi: https://doi.org/10.1101/2021.04.28.21256245; this version posted May 1, 2021. The copyright holder for this preprint (which was not certified by peer review) is the author/funder, who has granted medRxiv a license to display the preprint in perpetuity. It is made available under a CC-BY-NC-ND 4.0 International license.

\section{3. Generalised additive model (Model 2) results}

\section{$741 \quad 3.1$ Daily risk of patient nosocomial SARS-CoV-2 infection (model $P 2$ )}

742 Figure S2. Daily probability of having a first positive SARS-CoV-2 PCR test during

743 hospitalisation. The coloured lines represent the daily probabilities of having the first positive

744 SARS-CoV-2 PCR test throughout a patient's hospitalisation for months from February to

745 September 2020. These probabilities are predictions from the generalised additive model with a

746 logit link, with the binary outcome of assumed acquisition (yes/no) on each day as the dependent

747 variable, and infectious patients and healthcare workers as the independent variables. Infectious

748 patients were classified as having nosocomial SARS-CoV-2 infections with the assumption of a

749 5-day incubation period.

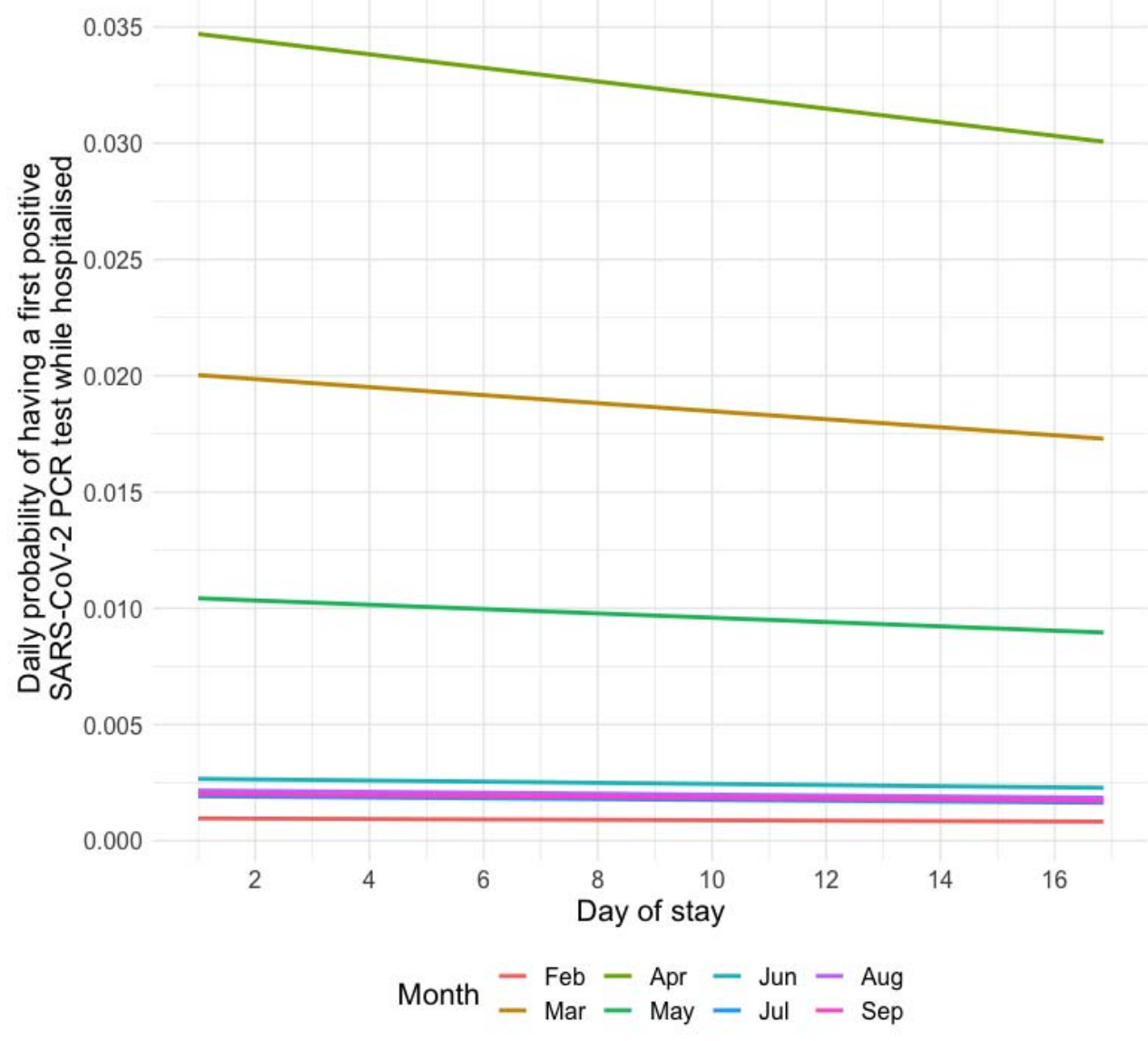




\section{4. Generalised linear model with identity link (Model 3)}

\section{4.1 Model comparison}

753 To quantify the daily transmission risk posed by infectious patients and healthcare workers, we

754 used a generalised linear mixed model with an identity link, thus allowing for the daily

755 probability of infection to scale linearly with infection pressure from healthcare workers and

756 patients and for their effects to be additive. Two models, one with interaction terms between the

757 phases and forces of infection from patients and healthcare workers, and one without the

758 interaction terms, were compared. Between these transmission models, the model with the best

759 fit to data by WAIC was the one without interaction terms, which has an intercept $(\alpha)$,

760 representing the infection risk not explained by covariates, and slopes (beta) which represent the

761 infection risk associated with infectious patients (community- and hospital-acquired) and

762 healthcare workers. 
medRxiv preprint doi: https://doi.org/10.1101/2021.04.28.21256245; this version posted May 1, 2021. The copyright holder for this preprint (which was not certified by peer review) is the author/funder, who has granted medRxiv a license to display the preprint in perpetuity.

It is made available under a CC-BY-NC-ND 4.0 International license.

765 Table S3: Comparison of widely applicable information criterion between a model with no

766 interaction terms between phases and infection pressure from patients and healthcare workers

767 versus a model with interaction terms.

768

\begin{tabular}{|c|c|c|c|c|}
\hline $\begin{array}{c}\text { Susceptible } \\
\text { host }\end{array}$ & Transmission model & Parameters & Priors & WAIC $\dagger$ \\
\hline \multirow[b]{2}{*}{ 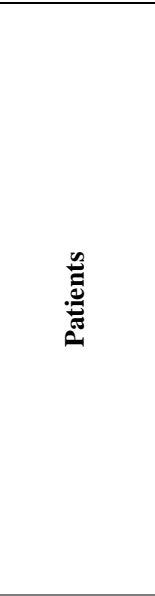 } & $\begin{array}{l}\text { No interactions terms } \\
\text { between phases and } \\
\text { infection pressure from } \\
\text { patients and healthcare } \\
\text { workers }\end{array}$ & $\begin{array}{l}\alpha \text { (intercept) } \\
\beta_{1} \text { (probability of transmission from infectious } \\
\text { patients with community-acquired SARS-CoV-2) } \\
\beta_{2} \text { (probability of transmission from infectious } \\
\text { patients with hospital-acquired SARS-CoV-2) } \\
\beta_{3} \text { (probability of transmission from infected } \\
\text { healthcare workers) }\end{array}$ & Half normal $(0,7)$ & $-284,770$ \\
\hline & $\begin{array}{l}\text { Interactions terms between } \\
\text { phases and infection } \\
\text { pressure from patients and } \\
\text { healthcare workers }\end{array}$ & $\begin{array}{l}\alpha \text { (intercept) } \\
\beta_{1} \text { (probability of transmission from infectious } \\
\text { patients with community-acquired SARS-CoV-2) } \\
\beta_{2} \text { (probability of transmission from infectious } \\
\text { patients with hospital-acquired SARS-CoV-2) } \\
\beta_{3} \text { (probability of transmission from infected } \\
\text { healthcare workers) } \\
\gamma_{1} \text { (probability of transmission in phase 2) } \\
\gamma_{2} \text { (probability of transmission in phase } 3 \text { ) }\end{array}$ & Half normal $(0,7)$ & $-142,632$ \\
\hline \multirow{2}{*}{ 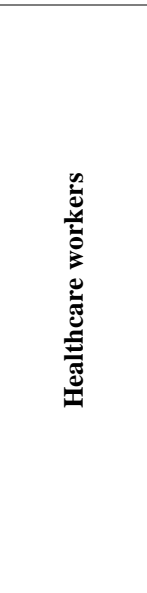 } & $\begin{array}{l}\text { No interactions terms } \\
\text { between phases and } \\
\text { infection pressure from } \\
\text { patients and healthcare } \\
\text { workers }\end{array}$ & $\begin{array}{l}\alpha \text { (intercept) } \\
\beta_{1} \text { (probability of transmission from infectious } \\
\text { patients with community-acquired SARS-CoV-2) } \\
\beta_{2} \text { (probability of transmission from infectious } \\
\text { patients with hospital-acquired SARS-CoV-2) } \\
\beta_{3} \text { (probability of transmission from infected } \\
\text { healthcare workers) }\end{array}$ & Half normal $(0,7)$ & $-19,285$ \\
\hline & $\begin{array}{l}\text { Interactions terms between } \\
\text { phases and infection } \\
\text { pressure from patients and } \\
\text { healthcare workers }\end{array}$ & $\begin{array}{l}\alpha \text { (intercept) } \\
\beta_{1} \text { (probability of transmission from infectious } \\
\text { patients with community-acquired SARS-CoV-2) } \\
\beta_{2} \text { (probability of transmission from infectious } \\
\text { patients with hospital-acquired SARS-CoV-2) } \\
\beta_{3} \text { (probability of transmission from infected } \\
\text { healthcare workers) } \\
\left.\gamma_{1} \text { (probability of transmission in phase } 2\right) \\
\gamma_{2} \text { (probability of transmission in phase } 3 \text { ) }\end{array}$ & Half normal $(0,7)$ & $-10,484$ \\
\hline
\end{tabular}




\section{$772 \quad 4.2$ Model assessment of the main analysis models}

773 Prior distributions were selected to be weakly informative half-normal distributions, such that the

774 prior values are kept positive. We assessed the models using measures of Markov chain

775 convergence including effective sample sizes and $R^{\wedge}$ which indicate if the chains had run for long

776 enough and had mixed well.

777

778 Plots of iterations vs. sampled values for model parameters in the MCMC chains. The three

779 different chains are plotted using different colours.

780

781 In the main analysis model where the outcome is hospital-acquired SARS-CoV2 infection

782 amongst the patients, the $R^{\wedge}$ values were about 1 and the minimum effective sample size was

7831700 across all parameters. The chains mixing is shown below. 
medRxiv preprint doi: https://doi.org/10.1101/2021.04.28.21256245; this version posted May 1, 2021. The copyright holder for this preprint (which was not certified by peer review) is the author/funder, who has granted medRxiv a license to display the preprint in perpetuity.

It is made available under a CC-BY-NC-ND 4.0 International license .

786 Figure S3. Model where outcome is patient SARS-CoV-2 infection acquired during

787 hospitalisation. First plot of each parameter, representing a single ward is shown.
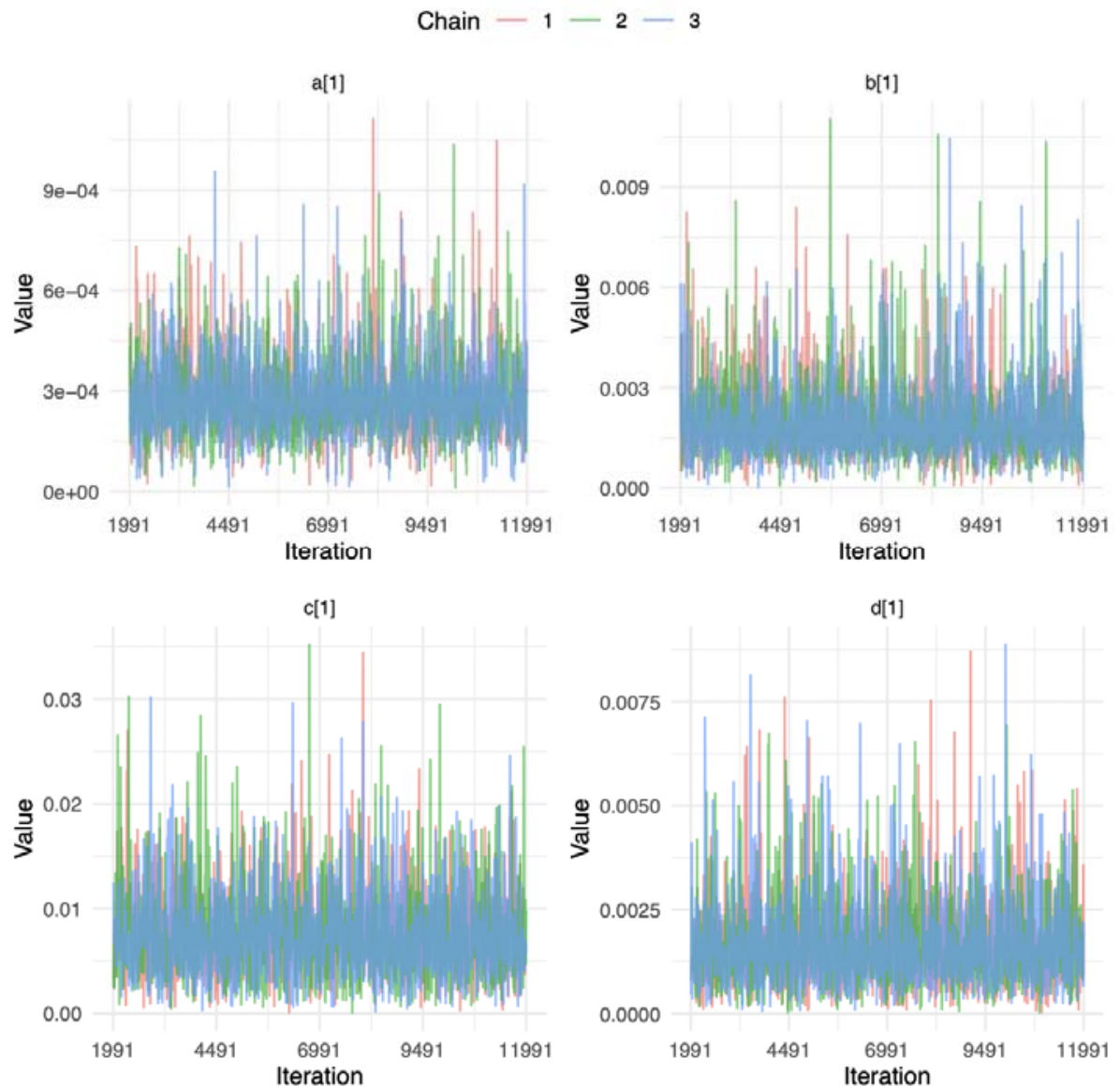

790 In the main analysis model where the outcome is hospital-acquired SARS-CoV2 infection

791 amongst the $\mathrm{HCW}$, the $R^{\wedge}$ values were about 1 and the minimum effective sample size was 1500

792 across all parameters. The chains mixing is shown below.

793

794 Figure S5: Model where outcome is healthcare worker SARS-CoV-2 infection. First plot of each 795 parameter, representing a single ward is shown. 
medRxiv preprint doi: https://doi.org/10.1101/2021.04.28.21256245; this version posted May 1, 2021. The copyright holder for this preprint (which was not certified by peer review) is the author/funder, who has granted medRxiv a license to display the preprint in perpetuity.

\section{It is made available under a CC-BY-NC-ND 4.0 International license .}
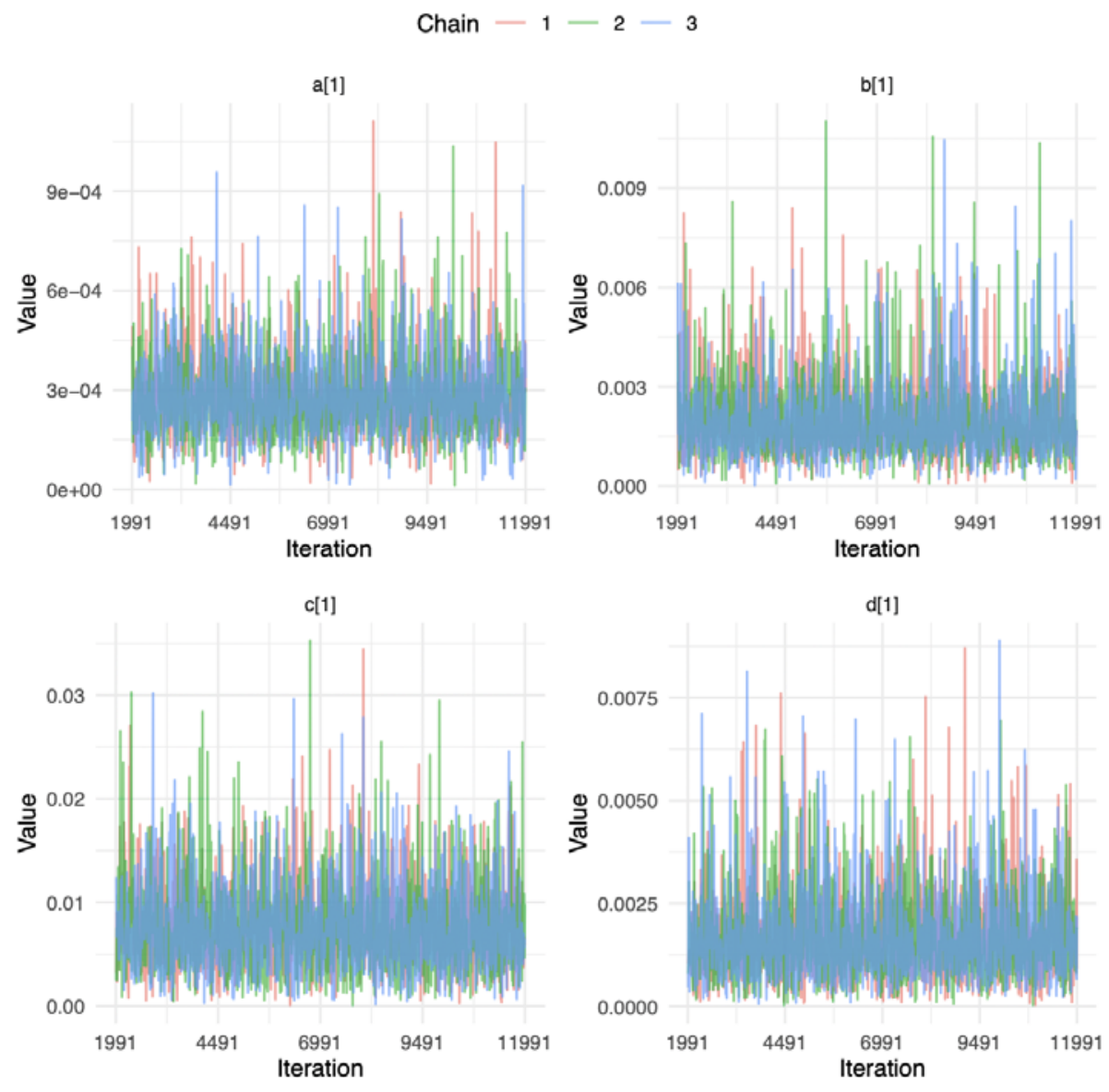
medRxiv preprint doi: https://doi.org/10.1101/2021.04.28.21256245; this version posted May 1, 2021. The copyright holder for this preprint (which was not certified by peer review) is the author/funder, who has granted medRxiv a license to display the preprint in perpetuity.

It is made available under a CC-BY-NC-ND 4.0 International license .

\section{Sensitivity analysis}

\subsection{Infectiousness scaled by day of infection according to incubation period}

Table S4: The main analysis considers infectiousness to be binary, i.e., absolute numbers of

801 infectious patients and healthcare workers in a ward on a particular day were used. Sensitivity

802 analysis considered infectiousness to be scaled according to the time since the day of infection

803 which, in turn, is based on an assumed incubation period of five days. This scaling of the number

804 of infectious patients and healthcare workers in a ward on a particular day makes use of the

805 relative infectiousness distribution derived by He et al [25] such that the sum of daily terms for a

806 single infected patient who was present in the ward throughout their entire infectious period

807 would equal one. Hence, the scaled parameters are an order of magnitude higher than the binary

808 infectiousness model estimates.

809

\begin{tabular}{|l|c|c|c|c|}
\hline \multirow{2}{*}{\begin{tabular}{l}
\multirow{2}{*}{$\begin{array}{c}\text { Infectious } \\
\text { population posing } \\
\text { transmission risk }\end{array}$} \\
\cline { 2 - 5 }
\end{tabular}} & \multicolumn{4}{|c|}{$\begin{array}{c}\text { Additional risk of acquiring nosocomial SARS-CoV-2 (\%) } \\
\text { (mean, 95\% credible interval) }\end{array}$} \\
\cline { 2 - 5 } & $\begin{array}{c}\text { Binary } \\
\text { infectiousness } \\
\text { (main analysis) }\end{array}$ & $\begin{array}{c}\text { Scaled } \\
\text { infectiousness }\end{array}$ & $\begin{array}{c}\text { For susceptible healthcare workers } \\
\text { infectiousness } \\
\text { (main analysis) }\end{array}$ & $\begin{array}{c}\text { Scaled } \\
\text { infectiousness }\end{array}$ \\
\hline $\begin{array}{l}\text { Background } \\
\text { infection risk } \\
\text { including } \\
\text { undetected cases }\end{array}$ & $0.03(0.02-0.03)$ & $0.03(0.03-0.04)$ & $0.02(0.02,0.03)$ & $0.03(0.02,0.04)$ \\
\hline $\begin{array}{l}\text { Patients who } \\
\text { acquired the } \\
\text { infection from the } \\
\text { community on the } \\
\text { same ward }\end{array}$ & $0.20(0.16-0.22)$ & $1.96(1.6-2.23)$ & $0.05(0.03,0.07)$ & $0.60(0.33,0.76)$ \\
\hline $\begin{array}{l}\text { Patients who } \\
\text { acquired the } \\
\text { infection from } \\
\text { the hospital on } \\
\text { the same ward }\end{array}$ & $0.75(0.55-0.95)$ & $6.56(5.33-7.94)$ & $0.11(0.08,0.15)$ & $1.01(0.70,1.32)$ \\
\hline $\begin{array}{l}\text { Healthcare workers } \\
\text { on the same ward }\end{array}$ & $0.17(0.13-0.22)$ & $1.45(1.01-1.91)$ & $0.10(0.04,0.20)$ & $0.83(0.31,1.62)$ \\
\hline
\end{tabular}


medRxiv preprint doi: https://doi.org/10.1101/2021.04.28.21256245; this version posted May 1, 2021. The copyright holder for this preprint (which was not certified by peer review) is the author/funder, who has granted medRxiv a license to display the preprint in perpetuity.

It is made available under a CC-BY-NC-ND 4.0 International license .

\section{$810 \quad 5.2$ Sensitivity to choice of prior distributions}

811 Table S5: Prior distributions for the various parameters were changed to test the sensitivity of the

812 estimates to the choice of prior distributions.

\begin{tabular}{|c|c|c|c|c|}
\hline \multirow{3}{*}{$\begin{array}{c}\text { Infectious } \\
\text { population posing } \\
\text { transmission risk }\end{array}$} & \multicolumn{4}{|c|}{$\begin{array}{l}\text { Additional risk of acquiring nosocomial COVID-19 (\%) } \\
\text { (mean, 95\% credible interval) }\end{array}$} \\
\hline & \multicolumn{2}{|c|}{ For susceptible patients } & \multicolumn{2}{|c|}{ For susceptible healthcare workers } \\
\hline & $\begin{array}{c}\alpha: \text { half normal }(0,7) \\
\beta: \text { half } \operatorname{normal}(0,7) \\
\quad \text { (main analysis) }\end{array}$ & $\begin{array}{c}\alpha: \text { half normal }(0,7) \\
\beta: \text { half normal }(0.01,3)\end{array}$ & $\begin{array}{c}\alpha: \text { half normal }(0,7) \\
\beta: \text { half normal }(0,7) \\
\quad \text { (main analysis) }\end{array}$ & $\begin{array}{c}\alpha: \text { half normal }(0,7) \\
\beta: \text { half normal }(0.01,3)\end{array}$ \\
\hline $\begin{array}{l}\text { Background } \\
\text { infection risk } \\
\text { including } \\
\text { undetected cases }\end{array}$ & $0.03(0.02-0.03)$ & $0.03(0.02-0.03)$ & $0.02(0.02,0.03)$ & $0.02(0.02,0.03)$ \\
\hline $\begin{array}{l}\text { Patients who } \\
\text { acquired the } \\
\text { infection from the } \\
\text { community on the } \\
\text { same ward }\end{array}$ & $0.20(0.16-0.22)$ & $0.20(0.16-0.22)$ & $0.05(0.03,0.07)$ & $0.05(0.03,0.07)$ \\
\hline $\begin{array}{l}\text { Patients who } \\
\text { acquired the } \\
\text { infection from } \\
\text { the hospital on } \\
\text { the same ward }\end{array}$ & $0.75(0.55-0.95)$ & $0.74(0.56-0.95)$ & $0.11(0.08,0.15)$ & $0.11(0.07,0.15)$ \\
\hline $\begin{array}{l}\text { Healthcare } \\
\text { workers on the } \\
\text { same ward }\end{array}$ & $0.17(0.13-0.22)$ & $0.16(0.13-0.22)$ & $0.10(0.04,0.20)$ & $0.11(0.04,0.20)$ \\
\hline
\end{tabular}

813 
medRxiv preprint doi: https://doi.org/10.1101/2021.04.28.21256245; this version posted May 1, 2021. The copyright holder for this preprint (which was not certified by peer review) is the author/funder, who has granted medRxiv a license to display the preprint in perpetuity.

It is made available under a CC-BY-NC-ND 4.0 International license .

\section{6. Model codes}

815 Code block 1: Logistic regression model using patient infection as the dependent variable.

817 glm.logistic.model <- glm(outcome $\sim$ age + sex + "ethnic group ‘ + 'infectious patients on the

818 same ward (community-acquired) ${ }^{\prime}+$ 'infectious patients on the same ward (hospital-acquired) $^{\circ}$

$819+$ 'infectious staff on the same ward' + 'hospital id' + 'type of ward' + phase +

820 splines::ns( 'Calendar day', 2), data = dat, family = 'binomial')

821

822 Code block 2: Generalised additive model using patient infection as the dependent variable, and

823 taking demographic factors, calendar day, day of hospitalisation, and number of infectious

824 patients and healthcare workers on the same ward per day as independent variables.

826 gam.model <- gam(outcome $\sim \mathrm{s}$ ('calendar day') $+\mathrm{s}($ 'day of stay') + s('patient absolute

827 nosocomial') + s('HCW absolute') + age + sex + 'ethnic group' + 'type of ward' + 'hospital

828 id' + phase, family=binomial(link = 'logit' $)$, data = dat $)$

830 Code block 3: Generalised linear mixed model with identity link (implemented in R with JAGS

831 using a non-centred parameterisation).

832

833 glm.identity.model <- function ()\{

834 \# Likelihood:

835 for $(\mathrm{i}$ in $1: \mathrm{N})\{$ 
$836 \quad$ outcome $[\mathrm{i}] \sim \operatorname{dbern}(\mathrm{mu}[\mathrm{i}])$

$837 \mathrm{mu}[\mathrm{i}]<-\mathrm{a}$ [admission_ward_index[i]] + b[admission_ward_index[i]] * 'Infectious patients on

838 the same ward (community-acquired)' $[\mathrm{i}]+\mathrm{c}[$ admission_ward_index[i]] * 'Infectious

839 patients on the same ward (hospital-acquired) '[i] + d[admission_ward_index[i]] * ،

$840 \quad$ Infectious staff on the same ward'[i]

$841 \quad$ \# For WAIC computation

$842 \quad$ loglike[i] <- dbin(outcome[i], mu[i], 1)

$843\}$

844 for (w in 1:N_ward)\{

$845 \mathrm{a}[\mathrm{w}]<-\mathrm{a} 0+\operatorname{aprimed}[\mathrm{w}] * \operatorname{sigma} . \mathrm{a} b[\mathrm{w}]<-\mathrm{b} 0+\operatorname{bprimed}[\mathrm{w}] *$

$846 \quad$ sigma.b c $[\mathrm{w}]<-\mathrm{c} 0+\operatorname{cprimed}[\mathrm{w}] * \operatorname{sigma} . \mathrm{c} \mathrm{d}[\mathrm{w}]<-\mathrm{d} 0+$

847 dprimed $[\mathrm{w}] *$ sigma.d aprimed $[\mathrm{w}] \sim \operatorname{dnorm}(0,1) ; \mathrm{T}(0$,

$848 \quad \operatorname{bprimed}[\mathrm{w}] \sim \operatorname{dnorm}(0,1) ; \mathrm{T}(0,) ; \operatorname{cprimed}[\mathrm{w}] \sim \operatorname{dnorm}(0,1) ; \mathrm{T}(0$,

$849 \quad$ dprimed $[\mathrm{w}] \sim \operatorname{dnorm}(0,1) ; \mathrm{T}(0$,$) ;$

$850 \quad\}$

$851 \quad$ \# Priors:

$852 \mathrm{a} 0 \sim \operatorname{dnorm}(0,0.1) ; \mathrm{T}(0,) ; \operatorname{sigma} . \mathrm{a} \sim \operatorname{dunif}(0,05) ; \mathrm{b} 0 \sim$

$853 \operatorname{dnorm}(0.01,0.1) ; \mathrm{T}(0$,$) ; sigma.b \operatorname{dunif}(0,1) ; \mathrm{c} 0 \sim$

$854 \operatorname{dnorm}(0.01,0.05) ; \mathrm{T}(0$,$) ; sigma.c \sim \operatorname{dunif}(0,1) ; \mathrm{d} 0 \sim$

855 dnorm $(0.01,0.05) ; \mathrm{T}(0$,$) ; sigma.d \sim \operatorname{dunif}(0,1)$;

$856\}$

857 


\section{7. Combined nasal and oropharyngeal swabs}

859 RT-PCR was performed using the Public Health England SARS-CoV-2 assay (targeting the

860 RdRp gene), one of five commercial assays: Abbott RealTime (targeting RdRp and N genes;

861 Abbott, Maidenhead, UK), Altona RealStar (targeting E and S genes; Altona Diagnostics,

862 Liverpool, UK), Cepheid Xpert® Xpress SARS-CoV-2 (targeting N2 and E; Cepheid, California,

863 USA), BioFire® Respiratory 2.1 (RP2.1) panel with SARS-CoV-2 (targeting ORF1ab and

864 ORF8; Biofire diagnostics, Utah, USA), Thermo Fisher TaqPath assay (targeting S and N genes,

865 and ORF1ab; Thermo Fisher, Abingdon, UK) or using the ABI 7500 platform (Thermo Fisher,

866 Abingdon, UK) with the US Centers for Disease Control and Prevention Diagnostic Panel of two

867 probes targeting the $\mathrm{N}$ gene.

868

869 


\section{Distributions of incubation period and generation time}

871 Figure S5: Distribution of the incubation periods, generation time (Panel A), and from symptom

872 onset to onward infection (Panel B).

873

874

875

876

877

878

879

880

881

882

883

884
A

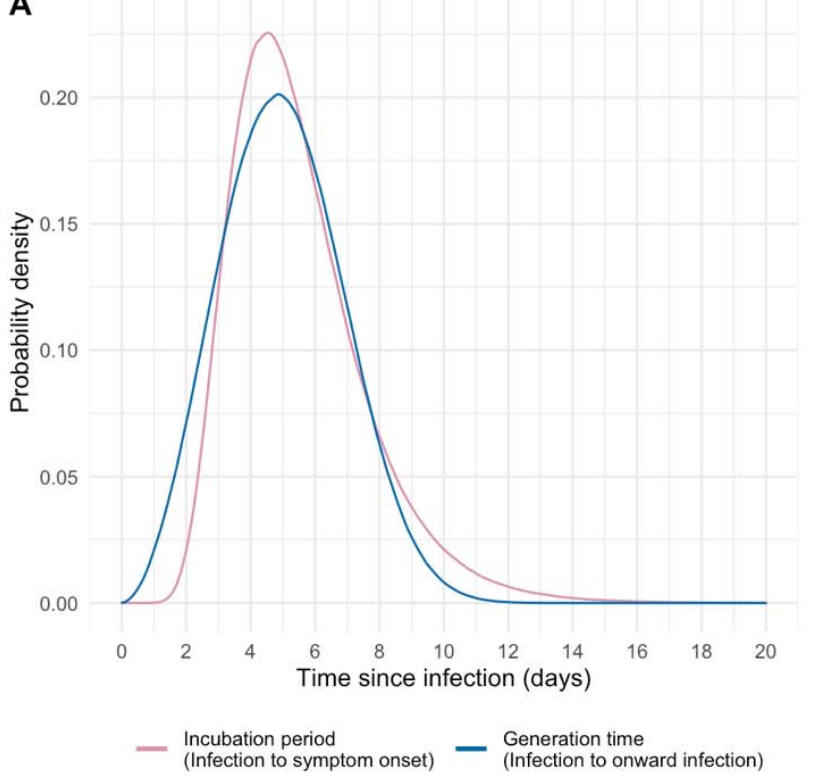

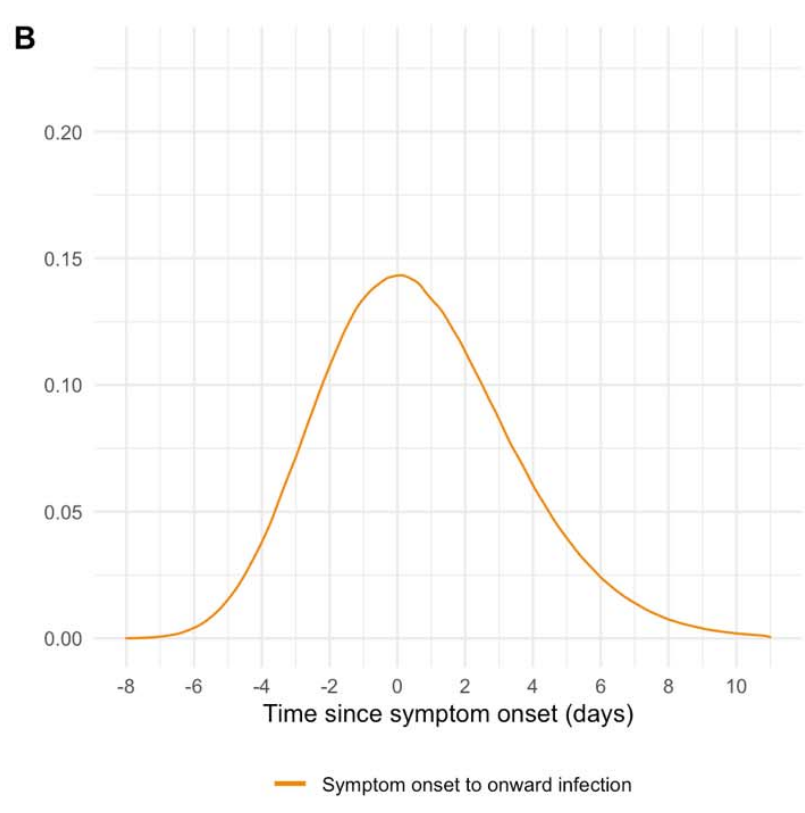

B

- Symptom onset to onward infection

\section{References:}

1. He X, Lau EHY, Wu P, Deng X, Wang J, Hao X, Lau YC, Wong JY, Guan Y, Tan X, Mo X, Chen Y, Liao B, Chen W, Hu F, Zhang Q, Zhong M, Wu Y, Zhao L, Zhang F, Cowling BJ, Li F, Leung GM. Temporal dynamics in viral shedding and transmissibility of COVID-19. Nat Med. 2020 May;26(5):672-675. doi: 10.1038/s41591-020-0869-5. Epub 2020 Apr 15. Erratum in: Nat Med. 2020 Sep;26(9):1491-1493. PMID: 32296168.

2. Ferretti L, Wymant C, Kendall M, Zhao L, Nurtay A, Abeler-Dörner L, Parker M, Bonsall D, Fraser C. Quantifying SARS-CoV-2 transmission suggests epidemic control with digital contact tracing. Science. 2020 May 8;368(6491):eabb6936. doi: 10.1126/science.abb6936. Epub 2020 Mar 31. PMID: 32234805; PMCID: PMC7164555. 
medRxiv preprint doi: https://doi.org/10.1101/2021.04.28.21256245; this version posted May 1, 2021. The copyright holder for this preprint (which was not certified by peer review) is the author/funder, who has granted medRxiv a license to display the preprint in perpetuity.

It is made available under a CC-BY-NC-ND 4.0 International license .

3. Lauer SA, Grantz KH, Bi Q, Jones FK, Zheng Q, Meredith HR, Azman AS, Reich NG, 


\section{Oxford COVID infection review team}

893 University of Oxford Medical School

894

- Hannah Chase

896

- Ishta Sharma

897

- Sarah Peters

898

- Archie Lodge

899

- Sai Parepalli

900

- Raghav Sudarshan

901

- Hannah Callaghan

902

- Imogen Vorley

903

- Gurleen Kaur

904

- Emel Yildirim

905

906 Oxford University Hospitals

907

- Omar Risk

908

909

- Tamsin Cargill

910

- Grace Barnes

- Josh Hamblin

- Jenny Tempest-Mitchell

913

- Ashley Elder

914

- Danica Fernandes

915

- Bara'a Elhag

916

- Edward David

917

- Rumbi Mutenga

- Dylan Riley 